\title{
The Quality of the Legal System, Firm Ownership, and Firm Size
}

\author{
Luc Laeven and Christopher Woodruff
}

\begin{abstract}
World Bank Policy Research Working Paper 3246, March 2004
The Policy Research Working Paper Series disseminates the findings of work in progress to encourage the exchange of ideas about development issues. An objective of the series is to get the findings out quickly, even if the presentations are less than fully polished. The papers carry the names of the authors and should be cited accordingly. The findings, interpretations, and conclusions expressed in this paper are entirely those of the authors. They do not necessarily represent the view of the World Bank, its Executive Directors, or the countries they represent. Policy Research Working Papers are available online at http://econ.worldbank.org.
\end{abstract}

\footnotetext{
* Laeven is at the World Bank and CEPR, and Woodruff is at the Graduate School of International Relations and Pacific Studies, UCSD. The authors thank Franklin Allen, Thorsten Beck, Luis Cabral, Simon Johnson, Ross Levine, Inessa Love, John McMillan, Bernard Yeung and seminar participants at the AEA 2004 annual meetings, Carnegie Mellon University, New York University, Pittsburgh University, Centro de Investigación y Docencia Económicas (CIDE), and the University of California at San Diego for helpful comments, Gerardo Leyva and Benito Arciniega for providing the data from the Mexican economic census, and Guillermo Noguera and Augusto Nieto for research assistance.
} 


\title{
The Quality of the Legal System, Firm Ownership, and Firm Size
}

\begin{abstract}
Employment in developing countries is disproportionately concentrated in very small firms. We examine the extent to which the distribution of firm size is related to the quality of the legal system using data from Mexico. We combine Lucas' (1978) model of firm size with Himmelberg, Hubbard and Love's (2001) consideration of idiosyncratic risk in a framework in which the distribution of entrepreneurial talent and aversion to idiosyncratic risk combine to determine the optimal size of firms. Our data allow us to focus on the differential impact of the legal system on proprietorships and corporations. Moreover, by focusing on firms in a single country, the data draw attention to the importance of variation in the administration of justice and the enforcement of legal verdicts. We find that Mexican states with more effective legal systems have larger firms. A one-standard deviation improvement in the quality of the legal system increases the average firm size by about 10-15 percent. The impact of the legal system is greatest in sectors in which proprietorships dominate. This pattern is consistent with better legal systems increasing the investment of firm owners by reducing the idiosyncratic risk they face. All of these findings are upheld when we instrument for institutional variables using the log of indigenous population in 1900 and the active presence of the drug trade in the state.
\end{abstract}




\section{Section 1: Introduction}

Firms finance investment through a combination of internal and external funds. Inducing investment from either source depends on some degree of legal protection. The willingness of firms to reinvest internally generated funds depends on protection of basic property rights (Besley 1995; Mauro 1995; Johnson, McMillan and Woodruff 2002a); the willingness of banks to lend depends on the ability to capture collateral pledged in support of loans (Levine 1998); and the willingness of outside equity investors to take a minority ownership position depends on protection against tunneling by insiders (Johnson, La Porta, Lopez-de-Silanes, Shleifer 2000).

The connection between the laws and the legal system on the one hand and financial market development on the other is well established in the literature. La Porta, Lopez-de-Silanes, Shleifer and Vishny [henceforth, LLSV] (1997, 1998) show that outsider shareholder rights are better protected in legal systems with roots in the English common law system than in the various civil law systems, implying variation in the ability of firms to access outside equity. Levine (1998) uses cross-country data to show that both creditor-friendly laws and higher quality legal systems are associated with better developed banking systems, implying variation in the ability of firms to access outside debt.

What is less well established in the literature is the relative importance of the legal system in generating internal and external equity investments. In this paper, we provide evidence on this question using data from a census of firms in Mexico. We use data on the legal form of the firms - proprietorships, partnerships and corporations - to examine the relative importance of the legal system on the size of firms owned by a single person 
(proprietorships), compared to firms with multiple owners (partnerships and corporations). An important distinction between these two is that in the former, owners face potentially higher levels of idiosyncratic risk. Controlling owners of partnerships and corporations diversify their risk at the cost of creating agency problems which may subject outside investors to stealing by insiders. ${ }^{1}$ Efficient legal systems reduce idiosyncratic risk, lowering the cost of internal investment funds, and limit the ability of insiders to steal from outside investors, lowering the cost of external investment funds. More efficient legal systems also increase the demand for investment capital by increasing the profitability of investments by a firm. This is a potentially important channel through which more efficient legal systems improve the efficiency with which capital is allocated in an economy.

This paper contributes to the existing literature on the relationship between legal systems, firm ownership, and firm size in three respects. First, our data allow us to focus on the differential impact of the legal system on different legal forms of organization, such as proprietorships and corporations, while the existing empirical literature generally does not distinguish between different legal types. ${ }^{2}$ Second, we focus on firms in a single country in which the legal system arose from a single legal family and in which the most important laws governing commercial transactions are national in scope. As such, the data draw attention to the importance of variation in the administration of justice and the enforcement of legal verdicts. Differences in the efficiency of property registration systems, in the quality of local police, and so forth, lead to differences in the efficiency of

\footnotetext{
${ }^{1}$ There is a large literature on the agency problems in corporations and partnerships (e.g., Alchian and Demsetz 1972, Holmstrom 1982, and Fama and Jensen 1983).

${ }^{2}$ The related empirical literature on entrepreneurship (e.g., Evans and Leighton 1989 and Evans and Jovanovic 1989) focuses mostly on all entrepreneurs - including sole proprietors, partners, and sole owners of incorporated businesses, but also does not generally distinguish between these different legal types.
} 
the legal system faced by firms located in different regions. Third, the existing empirical literature focuses mostly on data from large, publicly traded firms. Our data are from a census of all firms, giving more weight to small and medium-sized firms.

We adopt an approach that draws on the work of Kumar, Rajan and Zingales [henceforth, KRZ] (2002), who examine the determinants of firms size across 13 European countries. As in their work, our key dependent variable is the average size of firms in a given region and industry. KRZ find that more efficient legal systems are associated with larger firm sizes across countries in Western Europe, an effect especially pronounced in industries characterized by low levels of capital intensity. They posit that the reason for this is that all legal systems in Europe are of high enough quality to protect investment in physical capital. Variation among the European countries, therefore, shows up in the more challenging area of intangible assets such as intellectual property. Intangible assets are more important in less capital-intensive industries such as services. Our paper complements KRZ (2002) in that the legal environment in Mexico varies from bad to less bad, while the legal environment in Western Europe varies from good to very good. ${ }^{3}$ Hence, protection of more basic financial contracts is less certain in Mexico. Additionally, we examine explanations for firm size distribution other than legal systems, which have been offered in the development literature.

\footnotetext{
${ }^{3}$ Levine (1998) uses data from LLSV (1998) and shows that Mexico scores a 5.95 on a scale ranging from 1-10 in a measure of the efficiency with which contracts are enforced. Of the 15 European countries included in the KRZ (2002) sample, 11 score above 9, and an additional 3 between 8 and 9 on the same scale. Only Greece scores below 8, and its score is 6.40. The data in LLSV are averages over the period 1982-1995. More recent data on the LLSV measures show a similar, if not more pronounced, difference between Mexico and the Western European countries. The median rating of the Political Risk Services Group data averaged over the 1990-1999 period on rule of law for the KRZ (2002) sample of countries is 9.72, compared with a rating of 4.73 for Mexico. Even the lowest average score over the period 1990-1999 for the European countries on rule of law, 7.82 for Greece, is well above the score for Mexico.
} 
We combine Lucas' (1978) model of firm size with Himmelberg, Hubbard and Love's (2001) consideration of idiosyncratic risk in a framework in which the distribution of entrepreneurial talent and aversion to idiosyncratic risk combine to determine the optimal size of firms. The quality of the legal system affects firm size by reducing the level of idiosyncratic risk faced by the firm's owner(s), in a manner detailed below. Taking this framework to the data, we find that firms located in Mexican states with weak legal environments are smaller than those located in states with better legal environments. Moreover, we find that the effect of the legal system is larger for those industries in which proprietorships make up a larger percentage of the firms. Hence, the data provide support for the notion that improvements in the administration of the legal system are important in reducing idiosyncratic risk, and hence in drawing increased investment from owner-managed firms. This finding has particularly strong implications for developing countries, because employment in these countries is concentrated in very small firms.

The paper is organized as follows: The next section discusses the explanations of firm size existing in the literature, starting with the impact of the legal system, and presents a simple model of the link between firm size, firm ownership, and the quality of

the legal system. Section 3 then describes the data, Section 4 presents regression results, and Section 5 provides some discussion of the results and concludes.

\section{Section 2: Investment, Firm Size, and Legal Institutions}

We begin with a discussion of the impact of the legal system on firm size. Our data allow us to differentiate industries in which firms are predominately proprietorships owned by a single person, and industries in which firms are primarily corporations owned 
by multiple owners. We develop a simple analytical framework based on Lucas' (1978) model determining the distribution of firm size. Our intention is not to break new theoretical ground, but to derive a clear set of empirical predictions for our data by combining the ideas from several recent theoretical papers.

We first consider firm size distributions in an economy of corporations with multiple owners. This establishes a benchmark distribution of firm size, in accordance with the distribution of entrepreneurial talent. We then consider an economy of ownermanaged proprietorships. The proprietorships differ from corporations in two ways. First, they have a single owner, who bears all of the risk of losses from the business. Second, the owner's liability is unlimited. Creditors of the business can make claims on the owner's non-business assets. In this environment, we add a consideration of idiosyncratic risk and the quality of the legal system to the Lucas framework. For a fixed level of the entrepreneur's wealth, idiosyncratic risk is increasing in the owner's investment in the firm. Therefore, idiosyncratic risk will have the greatest impact among the highest ability entrepreneurs, those who would otherwise invest the largest amounts. An improvement in the quality of the legal system will reduce idiosyncratic risk, allowing an expansion of investment by higher ability entrepreneurs. In the limit, i.e., in a perfect legal system, the distribution among proprietorships will approach that of the benchmark case of the incorporated economy. The framework suggests that in an economy with a mixture of corporations and proprietorships, the relationship between firm size and the quality of the legal environment will be strongest where there is a larger proportion of proprietorships.

First, consider an economy composed of corporations only. Entrepreneurs produce output using capital, hired labor, and entrepreneurial input. As in Lucas's 
original paper, we assume entrepreneurs differ both in skill level and in span of control. Each agent has the potential to produce output $\mathrm{Y}$ using labor and capital according to $\mathrm{Y}=$ $\Omega \theta \mathrm{K}^{(\alpha)} \mathrm{L}^{(\beta-\alpha)}$, where $\alpha<\beta<1$. The parameter $\Omega$ indicates the quality of the legal system, with $\Omega \in[0,1] ; \theta$ is a measure of the entrepreneurial talent of the agent, with $\theta \in$ $[0,1]$, with talent increasing in $\theta$. Every entrepreneur faces decreasing returns to scale, ${ }^{4}$ but higher ability entrepreneurs produce higher levels of output both on average and at the margin than do lower ability entrepreneurs.

An entrepreneur with a given talent level produces more output where the legal system is more efficient. One channel through which the legal system affects the production function of an individual firm is through the demand for products. Better legal systems may increase the demand for a given firm's output, by increasing the number of available trading partners. In the absence of legally enforceable contracts, firms may limit transactions to trading partners who are well known to them (Johnson, McMillan and Woodruff, 2002b). Better legal systems allow trading relationships to develop more quickly, and hence expand the market for the lowest cost producers.

Given a continuous distribution of entrepreneurial talent, in equilibrium some agents will choose to become entrepreneurs and some will be wage workers hired by those who become entrepreneurs. The wage rate and rental rate of capital are determined endogenously by demand for capital and labor from entrepreneurs. ${ }^{5}$ Each agent weighs the profit from being an entrepreneur against the endogenously determined wage rate.

\footnotetext{
${ }^{4}$ Alternatively, we could write the production function as $\mathrm{Y}=\Omega \mathrm{K}^{(\alpha \theta)} \mathrm{L}^{(1-\alpha) \theta}$, in which the scale factor is a function of entrepreneurial ability. This produces identical predictions, though the calculation of derivatives is more difficult.

${ }^{5}$ As with trading partners, higher quality legal systems may also reduce the cost to firms of hiring workers who are outside their social circles. At the cost of added complexity, this could be modeled by making the firm's (effective) wage rate a function of the quality of the legal system.
} 
Given that all firms are corporations whose owners are fully diversified, we assume that all face the same interest rate, call it $r$, and pay the same wage rate, call it $w$. Each potential entrepreneur then chooses $\mathrm{K}$ and $\mathrm{L}$ according to:

(1) $\quad w=(\beta-\alpha) \theta \Omega K^{\alpha} L^{(\beta-\alpha-1)}$

(2) $\quad r=\alpha \theta \Omega K^{\alpha-1} L^{(\beta-\alpha)}$

Denote the levels of labor and capital that satisfy 1 and 2 as $\mathrm{L}^{*}(\theta)$ and $\mathrm{K}^{*}(\theta)$. Then the profit for an agent from self employment is $\mathrm{Y}\left(\mathrm{K}^{*}(\theta), \mathrm{L}^{*}(\theta)\right)-\mathrm{w} \mathrm{L}^{*}(\theta)-\mathrm{rK}^{*}(\theta)$. For a given level of $\mathrm{K}$ and $\mathrm{L}$, an increase in $\theta$ results in an increase in the right hand side of (1) and (2). Given that all firms face the same wage and capital rental rates, this implies that higher $\theta$ (more able) entrepreneurs will run larger firms. Indeed, Lucas (1978) shows that an equilibrium exists in which agents with the highest levels of entrepreneurial ability become entrepreneurs, and the remaining agents becoming wage workers. The cutoff between wage work and self employment is increasing in the (endogenously determined) wage rate. An increase in the wage rate leads to the lowest ability entrepreneurs closing shop and becoming wage workers. In this equilibrium, the distribution of firm size depends on the distribution of entrepreneurial talent and the economy's capital/labor ratio.

We now examine changes in the equilibrium distribution of firm size in an economy at the other extreme, where all firms are proprietorships, each of which is owned by a single agent. Investment comes from the personal wealth of the owner, invested directly or used as collateral for loans. We assume all loans are fully 
collateralized. ${ }^{6}$ Hence, borrowing capital does not reduce the risk to the owner. The owners face unlimited liability for losses incurred operating the business, and are unable to diversify risk. We assume both the production function and the distribution of entrepreneurial talent are as above. Following Himmelberg, Hubbard and Love (2001), we make an explicit consideration of idiosyncratic risk faced by firm owners. All agents earn the same rate of return on capital invested without risk (perhaps in government bonds) outside the business. However, the risk premium required for capital invested in the business, denoted as $\rho$, is increasing in the level of investment. For all levels of capital investment, $\rho \geq 1$ and $\rho_{\mathrm{K}}>0$. We assume further that the idiosyncratic risk is a decreasing function of the quality of legal enforcement. A better legal system provides a more certain operating environment, allows firms to protect profits from bureaucrats with kleptocratic tendencies, and so on. ${ }^{7}$

As before, maximizing agents choose labor according to equation (1). But the cost of capital now includes a return to idiosyncratic risk, so optimal investment is now:

$$
r \rho(K, \Omega)=\alpha \theta \Omega K^{\alpha-1} L^{(\beta-\alpha)},
$$

or:

$$
\text { (3a) } \quad r=\frac{\alpha \theta \Omega K^{\alpha-1} L^{(\beta-\alpha)}}{\rho(K, \Omega)}
$$

\footnotetext{
${ }^{6}$ This assumption which appears reasonable to Mexico, at least with respect to bank loans. See La Porta, Lopez-de-Silanes and Zamarripa, 2003.

${ }^{7}$ Besley (1995) shows that improved legal protection of property positively affects investment incentives and provides evidence for the importance of property rights in the context of land ownership by farmers in Ghana. Johnson, McMillan, and Woodruff (2002a) show for a sample of firms in post-communist countries that weaker property rights discourage the reinvestment of firm earnings, even when outside financing is available. Banerjee and Iyre (2002) find that agricultural investment is lower and agricultural production is less capital intensive in Indian states with weaker protection of property rights. Claessens and Laeven (2003) find results that indicate that secure property rights help firms to allocate resources better between tangible and intangible assets and to grow faster.
} 
We assume that all agents have similar aversion to idiosyncratic risk, and that the distribution of wealth and entrepreneurial ability are uncorrelated. The effect of idiosyncratic risk on the distribution of firm sizes can be seen by comparing the impact of an increase in $\theta$ on the level of capital (and labor) demanded by a single firm in equations (2) and (3a). As in equation 2, an increase in $\theta$ results in an increase in the numerator of (3a). Given market wage and rental rates, an increase in entrepreneurial ability results in an increase in the investment in both capital and labor. As the level of capital employed increases, however, the denominator of (3a) increases as well. Formally, for equation (2), $\partial^{2} \mathrm{Y} / \partial \mathrm{K} \partial \theta$ is $\alpha \Omega K^{\alpha-1} L^{(\beta-\alpha)}$; for equation (3a), the same cross partial adjusted for idiosyncratic risk is $\frac{\alpha \Omega K^{\alpha-1} L^{(\beta-\alpha)}}{\rho(K, \Omega)}$. Since the level of $\mathrm{K}$ is increasing in $\theta$, the latter is smaller, indicating that a change in entrepreneurial ability is associated with a smaller increase in the capital employed. Hence, an increase in entrepreneurial ability is associated with a smaller increase in the size of the firm when idiosyncratic risk is incorporated.

The consideration of idiosyncratic risk reduces the average firm size though an indirect route as well. The reduction in investment by the most able entrepreneurs will result in lower market wage rates. This will induce additional entry into self employment (partially offsetting the initial reduction in wage rates). The new entrants will have lower entrepreneurial ability than the marginal entrant in the economy without idiosyncratic risk, and hence will employ less capital and labor than the previous marginal entrant.

The situation is depicted in Figure 1, which shows the marginal product of capital for entrepreneurs of high and low ability, and the (equilibrium) market rental rate of capital. Also shown in the graph is the return required to entrepreneurs bearing 
idiosyncratic risk, given some fixed quality of the legal system. This is increasing in the level of capital invested. The decrease in capital invested resulting from a consideration of idiosyncratic risk is larger for higher ability entrepreneurs. The distance $\Delta \mathrm{K} \mid \theta_{\mathrm{L}}$ shows the reduction in capital investment for a low ability entrepreneur; $\Delta \mathrm{K} \mid \theta_{\mathrm{H}}$ shows the same reduction for a high ability entrepreneur. The latter is larger because idiosyncratic risk increases in capital investment.

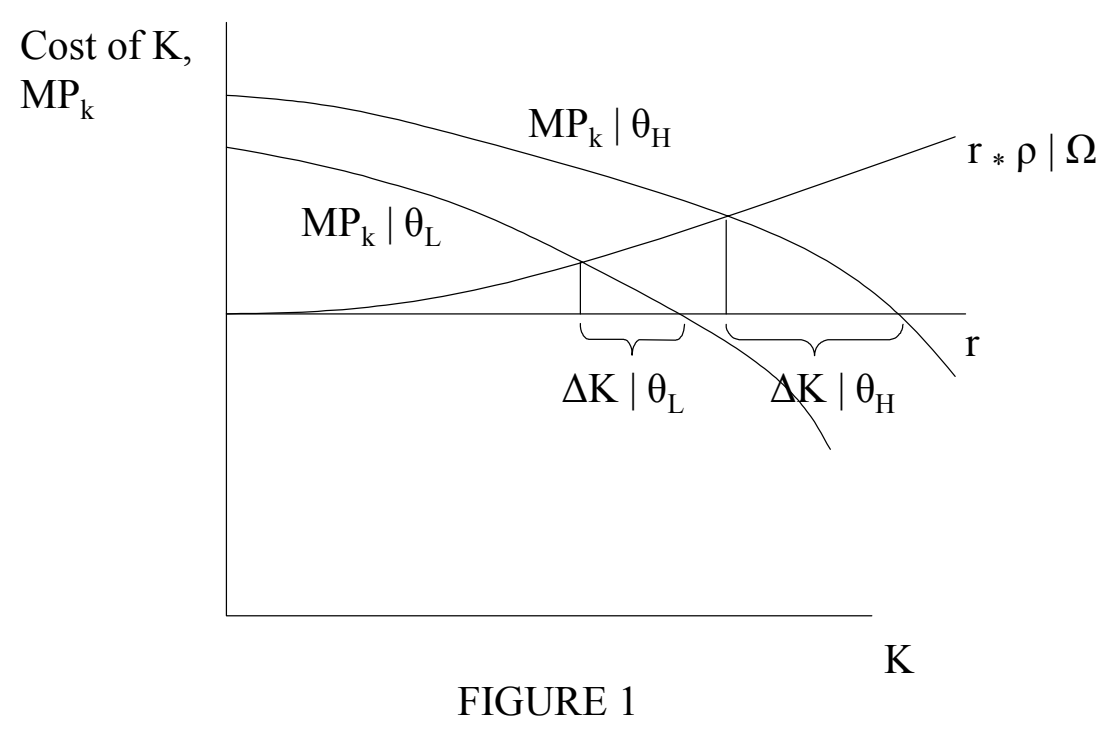

With this, we are now ready to consider how an improvement in the quality of the legal system affects the distribution of firm size. The legal system enters the production function directly, and may also impact investments by reducing the idiosyncratic risk faced by the entrepreneur. The direct production effect increases the demand for labor and capital from all entrepreneurs, raising wage and capital rental rates and inducing the entrepreneurs with the lowest ability levels to leave self employment for wage work. Thus, as above, the direct effect of an improvement in the legal system increases the 
average firm size by increasing the size of the largest firms and eliminating the smallest firms from the distribution.

An improvement in the legal system also reduces idiosyncratic risk wherever idiosyncratic risk is not eliminated through dispersed ownership. This will result in an additional increase in firm size wherever proprietorships are important. This gives us two strong predictions to take to the data. First, we should expect firm size to increase with the quality of the legal system under any form of ownership. Second, we should expect the impact of the legal system to be greatest where idiosyncratic risk plays a larger role, i.e., among proprietorships. In the next section, we show that the extent to which proprietorships are important varies across industries, and that inter-industry pattern in Mexico is similar to that in the United States.

Before moving to a discussion of the data, two comments about the framework are warranted. First, our analytical framework develops an argument around the demand for external and internally generated funds. Better legal systems might also expand the availability of credit from banks, perhaps by reducing the amount of collateral required for a loan of a given size (Levine 1998; Jappelli, Pagano and Bianco, 2002). Observed firm size may be impacted by the increase in the supply of finance. ${ }^{8}$ We discuss our attempt to deal with this issue empirically in Section 4. In the end, though, there remains a possibility that the effect of the legal system on firm size found in the data is affected by the supply of finance as well as its demand.

\footnotetext{
8 Evans and Jovanovic (1989) find that liquidity constraints negatively impact entrepreneurial activity. Similarly, Guiso, Sapienza, and Zingales (2002) study regional differences across Italy in the choice of being self-employed and find a higher level of entrepreneurial activity in provinces that are more financially developed.
} 
Second, although we have presented the extreme cases of corporate and proprietor economies, all economies in fact have a mixture of proprietorships and corporations. We limit ourselves to a very brief discussion of this issue here, intended only to point out that the effect of an improvement of the legal system on the number of corporations relative to proprietorships is theoretically ambiguous, Hence, the framework generates no testable hypotheses in this regard.

Given the advantage that outside owners provide in lowering the level of idiosyncratic risk, there obviously must be some cost in establishing a corporation. Several papers have focused on the threat of stealing, or tunneling, by inside owners (Shleifer and Wolfenzon, 2002; Lamoreaux and Rosenthal, 2003). Himmelberg, Hubbard and Love (2001) find evidence that the ability to tunnel is reduced when the quality of the legal system is improved. Outside ownership also implies the need for formal registration of the firm, and more formal accounting systems (Djankov, La Porta, Lopez-de-Silanes and Shleifer, 2002).

An improvement in the legal system reduces the cost of moving to the corporate form of organization by reducing the cost of finding outside partners. An improvement may also increase the benefits of incorporation by, for example, increasing the demand for the firm's goods (the direct effect of $\Omega$ on the production function). However, not all of the effects of an improvement in the legal system work toward increasing the benefits of incorporation. An improvement in the legal system also reduces the level of idiosyncratic risk among proprietors, reducing the benefits of incorporation and increasing the size of existing proprietorships. If these latter effects outweigh the former, an improvement in the quality of the legal system could result in a greater number of 
proprietorships relative to corporations. Theoretically, then, after accounting for the effect of idiosyncratic risk, there is no clear prediction with regard to the quality of the legal system and the distribution of legal forms.

In sum, an improvement in the legal system should be associated with an increase in firm size, regardless of the form of ownership. We expect the effect to be larger in industries where proprietorships are more important. There is no clear prediction on the effect of the quality of the legal system on the mix of employment in proprietorships and corporations.

\section{Other factors explaining firm size}

While our main interest here is the impact of the legal system on firm size, several other explanations of firm size have been offered by the literature. We review those briefly here, and include them in the regressions as controls. The additional explanations relate to the costs of regulation, levels of generalized trust, the size of the market, and the human capital of managers and workers.

Firms in heavily regulated environments may stay small in order to avoid attracting the attention of regulators. Rauch (1991) develops a model in which firms can avoid at least some of the costs of regulation if they remain small enough to stay under the bureaucrats' radar screen. This framework produces a clear prediction that increasing regulatory costs should be associated with a larger percentage of employment in very small firms, and a smaller overall firm size. An alternative view of the effect of regulation comes from Hopenhayn (1992), who focuses on the regulatory costs associated 
with the establishment of a new firm. Hopenhayn shows higher entry costs, by deterring entry, can lead to larger average firm size.

Regional data from India and Russia provide some evidence on the connection between the regulatory environment and investment tendencies of firms. For example, Besley and Burgess (2002) find that the burden of labor regulations on businesses varies greatly across states in India, and that more burdensome labor regulations are associated with lower investment, employment, productivity, and output among firms in the manufacturing sector. Slinko, Yakovlev and Zhuravskaya (2002) show that in Russian oblasts in which the legislature grants a greater number of benefits to specific firms, the growth rate of small firms is slower. Dollar, Iarossi and Mengistae (2002) find that in Indian states that are perceived by firm managers to have a poor investment climate, value added per worker is as much as 44 percent lower than in states with better investment climates.

Generalized trust is a measure of the extent to which people in a society feel that "most people can be trusted." Theoretically, the effect of generalized trust on firm size is not clear. Higher levels of generalized trust make cooperation easier to sustain, especially in interactions which are infrequent or occur between relative strangers. La Porta, Lopezde-Silanes, Shleifer and Vishny (1997) argue that such interactions are more likely to occur in very large organizations, and hence employment in large organizations should be increasing in the level of generalized trust. Firms which grow larger by increasing the volume of output they produce - that is, through horizontal integration - also interact with a larger number of trading partners. These interactions are more likely to be successful in environments with higher levels of generalized trust. But firms may also 
grow larger by integrating vertically. Vertical integration replaces less frequently repeated supplier relationships with more frequently repeated employee relationships. We might, then, expect vertical integration to be decreasing in the level of generalized trust, and hence a negative correlation between generalized trust and firm size. We leave it to the data to decide the issue.

The size of the market in which the firms sell may also affect the size of firms. One rationale for a connection between firm size and market size is suggested by Rosenstein-Rodan (1943) and Murphy, Shleifer and Vishny (1989). They propose that goods may be produced by either craft or mass production technologies. Smaller markets may not be of sufficient size to support mass production, and the larger firms it brings. The association should be strongest for sectors in which there are large fixed costs of entry. In most of the sectors we examine, however, fixed entry costs appear to be very low even in the largest markets in Mexico (McKenzie and Woodruff, 2003).

Firm size may also be related to market size measured by income. One of the implications of the Lucas (1978) model is that firm size will be increasing in per capita income. As incomes increase, wage rates do as well. So long as the elasticity of substitution in production between capital and labor is less than unity, wage rates increase faster than the return to entrepreneurship for the marginal entrepreneur. Hence, the level of entrepreneurial talent representing the cutoff between self employment and wage work increases. The lowest ability entrepreneurs, who manage the smallest firms, shift to wage work, resulting in larger overall firm size. Whatever the underlying cause, KRZ (2002) find a very strong positive relationship between market size and firm size in European data. We include variables measuring the total employment in the sector and state, the log 
of the state's population, and the log of per capita income in the state. These are discussed in more detail in the next section.

Hirschman (1958) suggests that entrepreneurial talent might limit entry of firms in developing countries. Entrepreneurial talent is also, of course, central to the model developed by Lucas (1978). We have no direct measures of how the stock of entrepreneurial talent varies across states in Mexico, but we measure this with educational attainment rates. One issue in the data is that educational attainment and per capita income are highly correlated, making it difficult to separate the effects of the two variables.

Finally, there is also a literature on the strategic behavior of large firms with respect to preventing entry (Gilbert, 1989). Dominant firms may also capture government officials, encouraging them to harass those firms who do enter and preventing them from growing. Given the very large number of very small firms, we do not expect the entry story is relevant in Mexico. But we will test for whether large firms have the effect of preventing growth among smaller firms. We also test to see if the presence of foreign firms operating in a state and sector affects the size of firms.

\section{Section 3: The Data}

Our data on firm investment and employment levels come from the Mexican Economic Census of 1998 (INEGI 1998). Employment and investment data are given in reference to December 31, 1998. The economic census covers the manufacturing, commerce, services and construction sectors. Data are gathered for every location of each firm in Mexico, but the statistics institute (INEGI) does not make the firm level data 
available. Instead, these data were provided to us at the two digit industry level, by state and by employment size. There are as many as 12 size bins in each state/industry. These are 0-2 workers, 3-5 workers, 6-10 workers, 11-15 workers, 16-20 workers, 21-30 workers, 31-50 workers, 51-100 workers, 101-250 workers, 251-500 workers, 501-1000 workers and 1001 or more workers. So, for example, an observation in the data we obtained from INEGI is then the number of firms employing 6-10 workers in the textile industry located in the state of Jalisco.

We obtained from INEGI both the data for all firms and the data for domestic firms, those for which no part of the capital is foreign owned. As we are interested in domestic institutions, we focus on the data that exclude foreign owned firms. Results including the foreign firms are similar to those we report below. We eliminate several industries that are dominated by government-owned firms: oil and gas extraction, coal mining, water and electricity. We also eliminate the fishing industry, both because the industry remains dominated by cooperatives established with significant government assistance and because the regional location of fishing is determined by geography. Finally, the census data do not include firms involved in agricultural production, though agricultural processing firms are included. There are 32 states and 25 two-digit sectors, resulting in 800 potential state/sector data points. However, some sectors have no employment in some states, so for most state/industry regressions we have about 740 observations. ${ }^{9}$

\footnotetext{
${ }^{9}$ One drawback of the data is that they are derived from plant level data. Our framework and most of the theories explaining firm size distributions refer to enterprise level data rather than plant data.

Unfortunately, there is no way to aggregate the data at the enterprise level, and even if we could, it is not clear what institutional measures we would use for firms operating in multiple states. We discuss this issue further below.
} 
We start with a comparison of firm size distribution in Mexico and the United States using our data from the Mexican census and data from the U.S. census of firms. Table 1 presents for different size categories the total number of firms and employees for both Mexico and the United States. The data on the distribution of firms by firm size category are presented in panel $\mathrm{A}$, and the data on the distribution of the number of employees by firm size category are presented in panel B of Table 1 . The firm size categories are based on the number of employees. The data for Mexico are for the year 1998, and the data for the United States are for the year 1997. We report data both for all firms and for manufacturing firms only. The source of the U.S. data is the 1997 U.S. Economic Census from the U.S. Department of Commerce.

The average firm size in Mexico is much smaller than in the United States. While over 96 percent of firms in Mexico employ less than 10 employees, only about 78 percent in the United States do so. As a percentage of the total firms, the number of large firms with more than 500 employees is about eight times larger in the United States than in Mexico.

The differences between Mexico and the United States are even more pronounced for manufacturing firms. The total number of manufacturing firms covered is similar in order of magnitude for both countries, about 340,000 firms. However, these firms employ a much larger number of employees in the United States (almost 19 million) than in Mexico (just over 4 million). The reason is that a much larger proportion of Mexican firms has only a small number of employees. While only about half of the manufacturing firms in the U.S. employ less than 10 people, in Mexico this number exceeds 90 percent. The numbers confirm Tybout's (2000) observation that employment in developing 
countries (such as Mexico) is disproportionately concentrated in very small firms, compared to employment in richer countries (such as the United States). ${ }^{10}$

Next, we compare the distribution of legal form of organization in Mexico and the United States. Table 2 presents for different legal form categories the total number of firms and employment for both Mexico and the United States. In Mexico, a much larger share of employment is concentrated in individual proprietorships (38 percent vs. 6 percent in the U.S.). Since the majority of proprietorships are smaller firms, this finding is consistent with the firm size distribution results from Table 1.

Table 3 shows Mexican state level data for three measures of firm size and for the degree of foreign ownership of firms. The firm size measures are based on data for domestically-owned firms only. The first column shows the simple average firm size, calculated as the sum of employees and contract employees ${ }^{11}$ divided by the number of units reported in the census. For Mexico as a whole, there are an average of 13.6 employees per unit reporting in the census, which is close to the average in the median European country reported by KRZ (2002). As KRZ (2002) point out, the simple average number of employees per firm can be misleading because the average may be brought down by a large number of very small firms. For example, the average size of firms in an industry in which a single firm hires 10,000 employees and 9 firms hire 1 employee each is roughly 1,000 . If the same industry instead had 99 firms hiring 1 employee each, the average firm size would be roughly 100. But in the sense of most theories of firm size, these two industries are not as different as is indicated by the difference in simple average

\footnotetext{
${ }^{10}$ We find similar results if we compare Mexico with OECD countries other than the United States using data on firm size distribution of firms in OECD countries used before by Cabral and Mata (2002).

${ }^{11}$ In order to avoid labor laws requiring firms to share profits with employees, firms sometimes establish independent entities which exist only to hire and provide workers to the firm. These workers are reported as contract employees.
} 
firm size. Following Davis and Henrekson (1997), KRZ (2002) suggest an alternative calculation of employee-weighted firm size. Recalling that our data come in bins containing a range of employment totals, the employee weighted firm size is given by: $\sum_{b i n=1}^{n}\left(\frac{N_{b i n}^{e m p}}{N_{\mathrm{sec}}^{e m p}}\right) *\left(\frac{N_{b i n}^{e m p}}{N_{\mathrm{sec}}^{e s t a b}}\right)$, where $N_{b i n}^{e m p}$ is the total number of employees reported in the given bin, $N_{\text {sec }}^{\text {emp }}$ is the total number of employees in the sector, and $N_{\text {sec }}^{\text {estab }}$ is the number of establishments in the sector. This alternative measure of average firm size places more weight on larger firms, and hence dampens the impact of a large number of very small firms. The second column of Table 3 shows the employee-weighted average firm size. Indeed, this produces a significantly larger average firm size. For Mexico as a whole, the average firm size is now just over 1,100 employees, which again is close to the average in the median European country reported by KRZ (2002). Across states within Mexico, there is considerable variation in firm size by either measure. For example, the employee weighted average firm size ranges from 275 in the state of Zacatecas to more than 5,000 in the Federal District.

As a third measure of firm size, we take the percentage of total employment found in firms with 10 or fewer employees. This focuses attention on the very small establishments. The third column of Table 3 shows that over half of the employment in Mexico occurs in firms with 10 or fewer employees. Again, there is significant variation across states, with as little as one-third of employment in small firms in the Federal District and just more than two-thirds of employment in the state of Chiapas. As would be expected, the employee-weighted firm size measure and the percentage of 
employment in establishments with fewer than 10 workers are highly correlated, with a correlation coefficient of $-0.82 .^{12}$

The last column in Table 3 reports the share of total employment in firms with foreign-ownership for each state in Mexico. The share of foreign-owned firms in total employment ranges from as low as 11 percent in Nuevo Leon to as high as 52 percent in Chihuahua. On average, about 24 percent of employees are employed by firms with foreign ownership. These employees are concentrated in the large firms.

\section{Legal Institutions}

The second major component of our data is the quality of legal institutions. These come from a survey conducted under the direction of the Center for the Study of Law at the Instituto Tecnológico Autónomo de México (ITAM/GMA 1998). The ITAM project focused on collection of bank debt through local courts in each of Mexico's 32 federal entities. Bank debt was chosen as the focus of the ITAM/GMA study because banks are centralized, but must collect debts in the location of the debtor; that is, they must operate in the courts of each state. From our perspective, the focus of the study on the legal enforcement of financial contracts is fortunate, since finance is clearly an important channel trough which the legal system affects firm growth. The data gathered come from

\footnotetext{
${ }^{12}$ The use of plant level rather than enterprise level data has a clear impact on the weighted average firm size. The impact on the percentage of employment in firms with fewer than 10 employees is less clear. Firms with operations in multiple states are also likely to have operations which clear our minimum size level (10 employees) in each state in which they operate. If so, then they will show up as medium rather than small size even in our data, and will not affect the results using this measure of firm size. However, if there are a significant number of firms with multiple very small operations, either within or across states, then these will bias the data against finding the pattern we are looking for, because such small operations that are part of larger firms are unlikely to suffer to the same extent from a weak legal environment as small independent firms do. These divisions of large firms are likely to benefit from the increased access to finance of large firms and possibly from the internal capital markets of large firms (Lamont 1997 and Shin and Stulz 1998). Large firms are also generally thought to be able to deal better with an inefficient judicial system because they are better connected. To the extent this is true, every division of a large firm is expected to benefit from these connections.
} 
interviews with a total of 519 lawyers working for banks directly and as outside counsel (ITAM/GMA, p. 32).

While the relevant commercial laws are national in scope, state laws and state legal enforcement have an important effect on the ability of claimants to enforce verdicts. State laws vary, for example, on the ease with which collateral can be claimed by a victor in a court decision. We construct a measure of the efficiency of legal enforcement in each state by taking an average of the responses to seven different questions. Each of these questions reflects the judgment of lawyers in the survey, and each is scaled of one to five. The questions relate to: 1) the quality of judges (mean value 3.76 ); 2 ) the impartiality of judges $(1.94)^{13}$; 3) the adequacy of judicial resources $(1.88)$; 4) the efficiency of enforcement of rulings $(2.71)$; 5) the efficiency of the judicial administration more generally (2.69); 6) the cost, ease of use, and completeness of property registries (3.33); and 7) the adequacy of local legislation related to contract enforcement (3.14). The index is shown in the first column of Table 4. The Appendix shows the correlation among the 7 components of the index and also three more quantitative measures of the legal system which are included in the ITAM/GMA study: the percentage of the state budget spent on the judicial branch, the salary of judges relative to that of private sector workers in the same state with a university education, and the average number months a judicial proceeding takes. ${ }^{14}$ The seven-component index of judicial effectiveness is correlated

\footnotetext{
${ }^{13}$ Since the survey was administered to layers who generally work for banks, it could be that a high rating on "impartiality" actually reflects a bias in favor of the banks. Given Levine's (1998) finding that rules favoring creditors are associated with higher levels of financial development, we do not see this as a great concern.

${ }^{14}$ Both the impressionistic data on which we focus and the quantitative data have drawbacks. On the one hand, the lawyers' responses to questions related to the impartiality and efficiency of judges and their courts reflect precisely the measures we would expect to impact the decisions of firms. The drawback of these data is obviously that they reflect the subjective opinion of lawyers. On the other hand, data on the percentage of the state's budget spent on courts are objective, but more spending may reflect less rather
} 
with the more quantitative, resource-based, measures of the judiciary in the expected way, though none of the correlations is significant. States that dedicate a larger proportion of their budget to the judiciary have a higher level of judicial effectiveness $(\rho=.25)$, as do states in which judges earn higher salaries $(\rho=.20) .{ }^{15}$ States in which trials take a longer time to prosecute rate lower on the judicial effectiveness scale $(\rho=-.17)$.

A separate survey of business owners provides state level measures of the cost of regulation and a measure of generalized trust. The "Survey of Governance and Development of Enterprises in Mexico" (EGDE) was conducted by the Monterrey Institute of Technology (ITESM) in the first quarter of 2002. The survey gathered data from 3,969 firms, with at least 100 firms responding in each of Mexico's 32 states. We use the responses to two questions from this survey. The first asks managers to identify several categories of costs as a percentage of the firm's revenue. Among the categories is the cost of regulation and regulatory activities. Cross-country data on the cost of regulations related to the establishment of a business reported in Djankov et al. (2002) indicate that costs of regulation in Mexico are high but not exorbitant compared with other countries. Direct fees and time costs for establishing a business amount to 83 percent of GDP in Mexico, above the world average of 66 percent, but far from the highest in the world.

The EGDE survey indicates considerable variation in regulation costs across states within Mexico. The state level average cost of regulation is shown in the second

than more efficiency in the legal system. The quantitative data produce results which are similar to those we find using the impressionistic data.

${ }^{15}$ The ITAM/GMA survey report refers to general complaints in Mexico that judges are underpaid relative to what they might earn in the private sector. Our calculation of "real" judicial salaries divides nominal salary by the average earnings of full time workers with university degrees residing in urban areas in the same state. We find that in only 2 of Mexico's 32 states do judges on courts of first instance receive salaries below those in the private sector. 
column of Table 4. Across Mexico, the business owners reported that regulation costs averaged 3.45 percent of sales, with the state level averages ranging from 1.32 percent to 4.71 percent. The EGDE survey also provides our measure of generalized trust. Managers were asked whether they agreed or disagreed with the statement: "The majority of people are trustworthy." Responses were scaled from 1 (strongly disagree) to 7 (strongly agree). The average responses ranged from 2.7 in the state of Chiapas to 4.1 in several states, with a national average of 3.77 . We use the state level average response to this question as our measure of generalized trust.

The final column of Table 4 gives an indication of the level of financial development by state in Mexico as proxied by the ratio of private credit to GDP. These data are the best available indication on access to finance for firms. However, the data on private credit have a couple of potential problems. First, a substantial part of bank lending taking place outside Mexico City is attributed to the Federal District, due to internal reporting procedures at Mexican banks. As a result, credit figures from banks overstate the level of bank activity in the state of the Federal District and understate the level of bank activity elsewhere in the country. In the regressions where we include private credit to GDP we therefore exclude the observations from the state of the Federal District. Second, as mentioned before, previous research has shown financial market development itself is a function of the efficiency of the legal system (Levine 1998). To address this concern, we use the residual of a regression of private credit to GDP on our measure of judicial efficiency as financial development variable in our regressions. ${ }^{16}$

\footnotetext{
${ }^{16}$ From the 1998 census we only have data on interest expense of firms, not on debt. Interest payments are an imperfect measure of access to finance, and may be jointly determined with the measures of firm size which are our primary focus. Furthermore, interest rates paid by firms are likely to vary across states,
} 


\section{Legal form}

Because of the idiosyncratic risk that they bear, firms with single owners bearing unlimited liability (such as proprietorships) are less likely to invest and grow their firms in poor legal environments where the returns to their investments are poorly protected. Firms with limited liability and multiple owners (such as limited partnerships and corporations) diversify the risk of owners to a greater extent. In countries or regions with lower quality legal systems, we therefore expect firms to be smaller, and we expect this effect to be more pronounced for proprietorships, where the owners bear unlimited liability.

To explore the differential effect of the quality of the legal system on firms with differences in the degree of idiosyncratic risk, we construct a variable measuring the number of firms with limited liability and multiple owners as a percentage of all firms in a particular industry. We will refer to this variable as the incorporation intensity measure. We construct this measure both for Mexico and the United States. The category of firms with limited liability includes corporations and limited partnerships in the United States, and sociedades anonimas (SAs) and sociedades de responsabilidad limitada (SRLs) in Mexico. For simplicity, we refer to these as the corporate legal form, though in both the US and Mexico they include limited partnerships as well. The total number of firms includes these as well as individual proprietorships. We exclude other type of legal forms from these total figures. For Mexico, we also report the share of employment in firms with limited liability and multiple owners.

industries and firms of different sizes. As a result, we use state level data on the total amount of credit extended as a measure of access to finance. 
Table 5 shows the incorporation intensity by industry for both Mexico and the United States. A lower number indicates that proprietorships are a more typical legal form of organization in the given industry. A comparison of the U.S. and Mexican data confirms that the distribution of legal forms is sector-specific. The corporate form tends to be more common in the mining and manufacturing industries, while businesses with unlimited liability are common in the services and retail sectors. ${ }^{17}$

\section{Other Variables}

Our regressions also control for the effect of market size, scarcity of entrepreneurial talent, and the presence of dominant firms. Market size is measured with the log of total employment in the sector and state, along with the log of state per capita GDP. The log of population is used as an instrument for sectoral employment in the IV regressions.

The availability of entrepreneurial talent is measured by educational attainment levels at the state level. We use the percentage of the population aged 25 to 40 with at least 9 years of schooling, representing completion of lower secondary schooling, measured using the 1990 population census data. Results using upper secondary (high school) or university attainment are similar. Finally, in some regressions we control for the presence of large firms and foreign firms in the sector. For these regressions, the dependent variable is the level of employment in firms with 10 or fewer employees as a percentage of employment in firms with fewer than 250 employees. The presence of large firms is then measured as the level of employment in firms with more than 250

\footnotetext{
${ }^{17}$ Incorporation intensity is likely to depend on industry characteristics such as capital intensity, the ease of monitoring worker or manager effort, and so on. At the industry level, the correlation between incorporation intensity in the US and Mexico is 0.34 .
} 
employees as a percentage of total sectoral employment. The effect of the presence of foreign firms is measured as the level of employment in foreign firms as a percentage of total sectoral employment including foreign firms.

Correlations between the measures of firm size and the institutional variables are shown on Table 6. The log average firm size and the log employee-weighted firm size are uncorrelated, but the employee weighted firm size is strongly correlated with both the percentage of employment in firms with fewer than 10 employees $(-0.82)$ and with the percentage of employment in manufacturing sectors $(0.50)$. There is also a strong positive correlation between size measured by the employee weighted measure and the log population in the state, the log per capita income and the percentage of the population with 9 years or more of schooling. Size is correlated with judicial effectiveness, cost of regulation, and generalized trust in the expected way, though the correlations are significant only when size is measured by the percentage of employment in very small firms and then only for judicial effectiveness $(-0.43)$ and generalized trust $(-0.42)$. The direction of causation of correlations between judicial effectiveness and economic performance is, of course, not clear. This is an issue we will address in the empirical work below.

Note that some of the theories outlined above, particularly those related to access to financial capital, make predictions about firm size measured by capital investment levels rather than employment. Our information is organized instead by employment size. Given complementarity between capital and labor, this is not of great concern. We begin by examining the distribution of firm sizes. Our primary dependent variable is the employee weighted average firm size. The results are qualitatively similar when we use 
the percentage of employment occurring in firms with 10 or fewer employees. (These results are available from the authors.) We report results using this alternative measure of firm size only for those regressions which include a measure of the importance of large and foreign firms in the industry.

\section{Section 4: Empirical results}

Across industries, the variation in the size of firms is consistent with well established patterns (see the discussion in KRZ 2002). Average firm size is positively associated with capital intensity (measured as fixed assets per worker) and with wage levels. We are more interested in regional variation in the size of firms and we will use information on how institutional variables vary across states to investigate this.

We begin by aggregating all firm size classes at the sectoral level in each state, and running regressions using the employee weighted firm size at the state/industry level as the dependent variable. The regressions, reported in Panels A and B of Table 7, have 732 observations across 32 states and 25 industries. Not all industries are represented in each state. Although the regressions are based on state/industry level data, the institutional variables of course vary only at the state level.

The regression model is as follows:

$$
\text { Size }_{i j}=\alpha_{i}+\beta \mathrm{B}_{j}+\gamma \Gamma_{i j}+\varepsilon_{i j}
$$

where Size $_{i j}$ is the average firm size of industry $\mathrm{i}$ in state $\mathrm{j}, \alpha_{i}$ is an industry fixed effect, $\mathrm{B}_{j}$ is a vector of state-level variables, $\Gamma_{i j}$ is a vector of variables that vary by industry and state, and $\varepsilon_{i j}$ is the error term. As state-level variables we include the $\log$ of per capita income, educational attainment, financial development, and the institutional 
variables judicial efficiency, cost of regulation, general trust. As state/industry level variable we include market size. Market size is measured by the log of total employment in the sector in the state. All regressions include sector level fixed effects.

Panel $\mathrm{A}$ in Table 7 reports random effects regressions for the above model. ${ }^{18}$ Market size has a very strong and positive effect on firm size. A one standard deviation increase in market size (1.8) is associated with a tripling of the weighted average size of firms. In the reported regressions, educational attainment is never significant, and per capita income is only sometimes significant. The significance of these two variables, however, is affected by collinearity between them. Either is significant at the 1 percent level when the other is excluded from the regression. All three of the institutional variables are significant with the expected sign. A one standard deviation increase in judicial effectiveness (0.56) increases the weighted firm size by 13 percent; a one standard deviation decrease in the cost of regulation (1.02) increases firm size by 8 percent; and a one standard deviation increase in the level of generalized trust $(0.31)$ increases firm size by 11 percent.

Column (4) of Panel A includes the financial development residual variable. We find that financial development (after controlling for judicial efficiency) is positively associated with firm size, although the effect is not statistically significant.

The fifth column of Panel A includes the employment in foreign firms as a percentage of total employment in the sector/state (including foreign firms). Here we find a positive association between firm size and the presence of foreign firms, although the effect is not statistically significant. Recall that the data used to calculate the dependent variable do not include foreign firms.

${ }^{18}$ GLS regressions with errors corrected for clustering at the state level produce very similar results. 
The sixth column of Panel A includes all three the institutional variables at the same time. ${ }^{19}$ We find that the regulatory cost variable changes sign and loses significance. The other variables, including judicial efficiency and generalized trust, change very little from the regressions which include those variables separately and remain statistically significant at the 5 percent level.

Several of the variables in the regressions reported in Panel A may be subject to endogeneity. For example, there may also be a direct connection between the presence of larger firms and the development of a more effective judicial system, in that larger firms may demand a better judicial system. We tackle these endogeneity issues by instrumenting for judicial effectiveness, the cost of regulation, the measure of generalized trust, financial development, and foreign ownership. For each of these institutional factors, we use two instruments. Following the lead of Acemoglu, Johnson and Robinson (2001) and Rodrik, Subramanian and Trebbi (2002), we use historical data to measure the component of the institutional environment which has deep historical roots. In particular, we use the $\log$ of the number of indigenous speaking people in the state in 1900. The encomienda system imported by the Spanish treated indigenous labor as a resource to be used by the immigrant Europeans. Hence, larger numbers of indigenous people might be expected to be associated with a worse institutional environment. The 1900 data is the earliest measure of indigenous population we could find at the state level. ${ }^{20}$

\footnotetext{
${ }^{19}$ We exclude the financial development and foreign ownership variables, because of their statistical insignificance in the previous regressions. Adding the financial development and foreign ownership variables does not qualitatively change the results.

${ }^{20}$ The states of Quintana Roo and Baja California Sur were created after 1900, carved out of Yucatán and Baja California, respectively. We use the data from Yucatán and Baja California, respectively. Given that there was essentially no population in 1900 in what is now the state of Quintana Roo, we might alternatively assign Quintana Roo a value of zero for indigenous population. Doing so makes most of the results stronger, so to be conservative we use the data for the Yucatán for Quintana Roo.
} 
As a second instrument, we note that Mexico has for a long time played a significant role in the flow of illegal drugs to the United States. In the past two decades, Mexico's role in drug trafficking has increased, especially following the increased intervention efforts along the Florida coast in the 1980s (Smith 1997). Arguably, involvement in drug trafficking is driven by geography rather than institutions. For example, the states along the Pacific coast of Mexico are all heavily involved in the drug trade. We expect that drug trafficking would undermine the quality of government and the level of generalized trust in those states in which trafficking is prevalent. Astorga (undated) lists the states with the largest cocaine seizures, marijuana production, poppy production as well as the states involved in heroin trafficking. We create a variable which takes a value of one if a state is one of the 16 states which shows up on Astorga's list, and zero otherwise. This variable is our second instrument for judicial quality. ${ }^{21}$

The two instruments explain 32 percent, 20 percent and 15 percent of the crossstate variation in judicial effectiveness, costs of regulation, and generalized trust, but only 6 percent and 11 percent of the cross-state variation in the financial development residual and foreign ownership variable.

Panel B of Table 7 presents the instrumental variables regressions, instrumenting for judicial effectiveness, regulatory costs, generalized trust, financial development, foreign ownership, and market size. In each of the regressions, we also instrument for the size of the market, using the log of the population in the state. The results are consistent with those reported in Panel A. Market size has a somewhat smaller but still substantial impact on firm size. Judicial effectiveness also has a slightly smaller measured effect,

\footnotetext{
${ }^{21}$ The states are Baja California, Baja California Sur, Chiapas, Chihuahua, Colima, the Federal District, Durango, Guerrero, Jalisco, Michoacán, Nayarit, Oaxaca, Quintana Roo, Sonora, Tamaulipas, and Vera Cruz.
} 
while regulatory costs and generalized trust have a larger measured effect. Generalized trust retains the expected sign but loses statistical significance. Our measures of financial development and foreign ownership remain insignificant. A one standard deviation change in judicial efficiency now corresponds to a 12 percent increase in weighted average firm size.

We find qualitatively similar results when we replace the weighted-average firm size with the percentage of employment found in firms with fewer than 10 employees (not reported). A significantly smaller percentage of employment is found in very small firms in states with better quality legal systems.

Next, we look for any effect that the presence of very large firms in an industry might have on the growth of smaller firms. To do this, we create a dependent variable which measures the percentage of employment in firms with 10 or fewer employees among those firms with 250 or fewer employees. We then include as independent variables the percentage of employment in very large firms (with more than 250 employees) in the sector as a whole. The results are presented in Panel C of Table 7. We find that the presence of large firms has no effect on the employment mix between small and medium sized firms, suggesting that large firms are not preventing smaller firms from growing. Again, we find that employment in states with better quality legal systems tends to be more concentrated among larger firms.

Panel D of Table 7 presents the instrumental variables results when we use the share of small firms in total employment as dependent variable. The effect of the legal system on this firm size distribution variable is somewhat smaller, although still significant at the 10 percent level. 
Next, we test whether the legal system has a greater effect on firm size in industries dominated by proprietorships than in those where corporations are more important. To explore this differential effect, we add to the regressions a variable measuring the percentage of firms in the industry which are corporations and the interaction of this term and the measure of the quality of the legal system.

The regression model now looks as follows:

$$
\operatorname{Size}_{i j}=\alpha_{i}+\beta \mathrm{B}_{j}+\gamma \Gamma_{i j}+\xi L_{i} \Omega_{j}+\varepsilon_{i j}
$$

where $L_{i}$ is the incorporation intensity in industry i and $\Omega_{j}$ is the quality of the legal system in state $\mathrm{j}$. The other variables are as before. Again, all regressions include sector level fixed effects.

Panel A of Table 8 reports both OLS regressions with state and industry fixed effects and regressions with state-level random effects and industry fixed effects. Again, we find that states with a more efficient legal system tend to have larger firms. In addition, we find that sectors in which firms predominantly operate as proprietorships (such as services) tend to have larger firms in states with a better legal environment. In other words, improved legal efficiency is particularly important for the growth of businesses where the owners have unlimited liability. Indeed, the negative coefficient on the interaction term is larger in magnitude than the positive coefficient on judicial efficiency. However, the standard deviation on incorporation intensity is only 0.20 , so the combined level and interaction effect is negative only for industries in the far upper tail.

The results do not alter substantially when instrumenting judicial efficiency and the market size variable with the same instruments used in Table 7. These results are presented in column 3 in panel B of Table 8 . In fact, the coefficient on the interaction 
term that is the interaction between judicial efficiency and incorporation intensity increases substantially when we instrument for both market size and judicial efficiency, although its statistical significance reduces somewhat.

We find qualitatively similar results when we define incorporation intensity in terms of employment rather than number of firms (not reported). This is hardly surprising given that the correlation between these two measures at the sectoral level is 0.94 .

Although we measure the incorporation intensity variable at the country level, this measure may be subject to endogeneity. For example, differences in judicial effectiveness at the country level may explain variation in the share of incorporated firms at the country level. $^{22}$

Tables 2 and 5 already showed that the U.S., a country with a more effective legal system than Mexico, has a larger proportion of incorporated firms. We therefore use data from the 1997 U.S. Economic Census to construct an incorporation intensity variable for the same industries based on U.S. data and check for robustness of the results. In doing this, we presume that firms in the United States do not face major obstacles arising from the institutional environment in their decision to incorporate or not, and therefore the sectoral distribution of legal forms of organization in the United States reflects the optimal distribution of legal forms across industries (see Rajan and Zingales (1998) for a similar argument when studying the external financial dependence of firms).

Panel B in Table 8 reports the results when using the U.S. benchmark data for the incorporation intensity measure rather than Mexican data. ${ }^{23}$ The results are qualitatively

\footnotetext{
${ }^{22}$ The country's legal system defines the organizational forms that firms can assume, and partly determines organizational choices (see, for example, North and Thomas 1973).

${ }^{23}$ These regressions exclude the construction industry. The Mexican economic census is composed of five sub-censuses: manufacturing, services, construction, mining, and financial services. A comparison of data
} 
similar, although the statistical significance of the results drops somewhat. This is not surprising given that the correlation between the U.S.-based and Mexican measures of incorporation intensity are is quite high, around 50 percent. These results suggests that to enhance growth it is important to protect the returns to investments, and that this is particularly important for (small) proprietorships that operate under unlimited liability.

\section{Section 5: Conclusions}

The average size of firms in Mexico varies with the quality of legal enforcement in the state in which the firm operates. States with more effective legal systems have larger firms. A one-standard deviation improvement in the quality of the legal system increases the average firm size by about $10-15$ percent. This finding suggests that the administration of the legal system is an important determinant of the prospects for firm growth. All states in Mexico have the same legal origin, and firms across the country are governed by the same legal code. What varies is the administration of laws and the enforcement of court verdicts.

The relationship between the quality of legal enforcement and firm size may be the result of any one or a combination of several effects. Better contract enforcement may allow trade with a broader set of trading partners, expanding a firm's market. Courts may also lead to an increase in the availability of external finance. Our empirical results provide some evidence, though, that one channel through which the legal system operates

from the census with data from Mexico's National Employment Survey (a household-based survey) indicates that in most of these sectors, a majority of the self employed were included in the census. This is not the case with the construction census, however, which appears to miss almost all of the self employed. Since about $25 \%$ of the employees in Mexico's construction sector work by themselves, we exclude the construction industry from our analysis. Note the especially large difference between Mexico and the United States in the proportion of proprietorships in the construction industry (see Table 5). 
is by reducing the idiosyncratic risk faced by the firm owners. The impact of the legal system is greatest in sectors in which proprietorships dominate. Better legal systems appear to increase the investment of firm owners by reducing the risk faced by owners. These results stand up even when we use U.S. data on the distribution of legal forms of organization. Arguably, the quality of the legal system in the United States offers the basis for an optimal distribution of legal forms, and the U.S. data offer therefore an ideal benchmark of a sector-specific legal organization of businesses. Moreover, all of these findings are upheld when we instrument for the institutional variables using the log of indigenous population in 1900 and the active presence of the drug trade in the state.

The quality of contract enforcement is not the only variable thath affects firm size. Among other determinants, the size of the market appears to have particular impact. Large markets contain much larger firms. Regulatory costs and generalized trust also have an impact on firm size, though when all three institutional variables are included in the regression together, the impact of regulatory cost becomes insignificant.

The size distribution of firms in a cross section is the result of a combination of size at startup and a dynamic growth process. The results imply that the legal system affects the growth prospects of firms. Where courts are more efficient, capital is shifted from entrepreneurs with less entrepreneurial ability to those with more entrepreneurial ability. These results suggest that policies that improve the administration of courts and the enforcement of verdicts would be expected to result in the growth of firms, an increase in the demand for workers, and a reduction in the rate of self employment. 


\section{Bibliography}

Acemoglu, Daron, Simon Johnson and James A. Robinson, 2001, “The Colonial Origins of Comparative Development: An Empirical Investigation," American Economic Review, Vol. 91(5), pp. 1369-1401.

Alchian, Armen A., and Harold Demsetz, 1972, "Production, Information Costs, and Economic Organization," American Economic Review, Vol. 62(5), pp. 777-795.

Astorga, Luís, "Drug Trafficking in Mexico: A First General Assessment," undated, UNESCO Management of Social Transformations Discussion Paper No. 36.

Banerjee, Abhijit and Lakshmi Iyre, 2002, "History, Institutions and Economic Performance: The Legacy of Colonial Land Tenure Systems in India," working paper, MIT.

Besley, Timothy, 1995, "Property Rights and Investment Incentives: Theory and Evidence from Ghana,” Journal of Political Economy, Vol. 103, pp. 903-937.

Besley, Timothy and Robin Burgess, 2002, "Can Labor Regulation Hinder Economic Performance? Evidence from India,” working paper, London School of Economics.

Cabral, Luis M.B. and Jose Mata, 2002, "On the Evolution of the Firm Size Distribution: Facts and Theory", American Economic Review, Forthcoming.

Claessens, Stijn and Luc Laeven, 2003, "Financial Development, Property Rights, and Growth," Journal of Finance, forthcoming.

Davis, Steven J., and Magnus Henrekson, 1997, "Explaining National Differences in the Size and Industry Distribution of Employment”, mimeo, University of Chicago. 
Djankov, Simeon, Rafael La Porta, Florencio Lopez-de-Silanes and Andrei Shleifer, 2002, “The Regulation of Entry," Quarterly Journal of Economics, Vol. 117(1), pp. 1-37.

Dollar, David, Giuseppe Iarossi and Taye Mengistae, 2002, "Investment Climate and Economic Performance: Some Firm Level Evidence from India," CREDPR Working Paper No. 143, Stanford University.

Evans, David S., and Linda S. Leighton, 1989, "Some Empirical Aspects of Entrepreneurship," American Economic Review, Vol. 79(3), pp. 519-535.

Evans, David S., and Boyan Jovanovic, 1989, "An Estimated Model of Entrepreneurial Choice under Liquidity Constraints," Journal of Political Economy, Vol. 97(4), pp. 808827.

Fama, Eugene F., and Michael C. Jensen, 1983, "Separation of Ownership and Control," Journal of Law and Economics, Vol. 26, pp. 301-325.

Gilbert, Richard, 1989, "Mobility Barriers and the Value of Incumbency," in: Richard Schmalensee and Robert D. Willig (eds.), Handbook of Industrial Organization, Volume 1, Chapter 8, pp. 475-536. Amsterdam: North Holland/Elsevier Science Publishers.

Guiso, Luigi, Paola Sapienza, and Luigi Zingales, 2003, "Does Local Financial Development Matter?," mimeo, University of Chicago.

Himmelberg, Charles, R. Glenn Hubbard, and Inessa Love, 2001, "Investor Protection, Ownership, and the Cost of Credit," working paper, Colombia University.

Hirschman, Albert, 1958, The Strategy of Economic Development, New Haven: Yale University Press. 
Holmstrom, Bengt, 1982, "Moral Hazard in Teams," Bell Journal of Economics, Vol. 13(2), pp. 324-340.

Hopenhayn, Hugo, 1992, "Entry, Exit and Firm Dynamics in Long Run Equilibrium," Econometrica, Vol. 60(5), pp. 1127-1150.

Instituto Tecnológico Autónomo de México and Gaxiola Moraila y Asociados, S.C. (ITAM/GMA), 1999, "La Administración de Justicia de las Entidades Mexicanas a Partir del Caso de la Cartera Bancaria," México City.

Jappelli, Tullio, Marco Pagano and Magda Bianco, 2002, "Courts and Banks: Effects of Judicial Enforcement on Credit Markets," CEPR Working Paper No. 3347.

Johnson, Simon, John McMillan and Christopher Woodruff, 2002a, "Property Rights and Finance," American Economic Review, Vol. 92(5), pp. 1335-1356. , 2002b, "Courts and Relational Contracts," Journal of Law, Economics and Organization, Vol. 18(1), pp. 221-77.

Kumar, Krishna, Raghuram Rajan and Luigi Zingales, 2002, "What Determines Firm Size," working paper, University of Chicago GSB.

Lamont, Owen, 1997, "Cash Flow and Investment: Evidence from Internal Capital Markets," Journal of Finance, Vol. 52, pp. 83-109.

Lamoreaux, Naomi and Jean-Laurent Rosenthal, 2003, "Organizing Middle Sized Firms in the United States and France, 1830-2000," working paper, UCLA.

La Porta, Rafael, Florencio Lopez-de- Silanes, Andrei Shleifer and Robert Vishny, 1997, “Legal Determinants of External Finance," Journal of Finance, Vol. 52, pp. 1131-1150. 
, 1998, "Law and Finance," Journal of Political Economy, Vol. 106,

pp. 1113-1155.

La Porta, Rafael, Florencio Lopez-de- Silanes, and Guillermo Zamarripa, 2003, "Related Lending," Quarterly Journal of Economics, Vol 118(1), pp. 231-68.

Levine, Ross, 1998, "The Legal Environment, Banks, and Long-run Economic Growth," Journal of Money Credit and Banking, Vol. 30(3) (Part 2), pp. 596-620.

Lucas, Robert E. Jr, 1978, "On the Size Distribution of Firms," Bell Journal of Economics, Vol. 9, pp. 508-523.

McKenzie, David, and Christopher Woodruff, 2003, "Do Entry Costs Provide an Empirical Basis for Poverty Traps?” Working paper, UCSD.

McMillan, John and Christopher Woodruff, 2002, "The Central Role of Entrepreneurs in Transition Economies," Journal of Economic Perspectives, Vol. 16(3), pp. 153-170.

Murphy, Kevin M., Andrei Shleifer and Robert W. Vishny, 1989, "Industrialization and the Big Push,” Journal of Political Economy, Vol. 97, pp. 1003-26.

North, Douglass, and Robert P. Thomas, 1973, The Rise of the Western World : A New Economic History, Cambridge University Press.

Rauch, James E., 1991, "Modeling the Informal Sector Formally," Journal of Development Economics, Vol. 35, pp. 33-47.

Rodrik, Dani, Arvind Subramanian and Francesco Trebbi, 2002, "Institutions Rule: The Primacy of Institutions Over Geography and Integration in Economic Development," working paper, Harvard University. 
Rosenstein-Rodan, Paul, 1943, "Problems of Industrialization in Eastern and Southeastern Europe,” Economic Journal, Vol. 53, pp. 202-11.

Shin, Hyun-Han, and René Stulz, 1998, “Are Internal Capital Markets Efficient?" Quarterly Journal of Economics, Vol. 113(2), pp. 531-552.

Shleifer, Andrei and Daniel Wolfenzon, 2002, "Investor Protection and Equity Markets," Journal of Financial Economics, Vol. 66, pp. 3-27.

Slinko, Irina, Yakovlev, Yevgeny and Zhuravskaya, Ekaterina, 2002, "State Capture in the Russian Regions," CEFIR working paper.

Smith, Peter, 1997, "Drug Trafficking in Mexico," in: Bosworth, Collins and Lustig, ed. Coming Together?: Mexico-US Relations. Washington, DC: Brookings Institution.

Tybout, James R., 2000, "Manufacturing Firms in Developing Countries: How Well Do They Do, and Why?," Journal of Economic Literature, Vol. 38. pp. 11-44. 


\section{Table 1. Firm Size Distribution in Mexico and the United States}

Panel A presents data on the distribution of firms by firm size category for Mexico and the United States, and Panel B presents data on the distribution of the number of employees by firm size category for Mexico and the United States. The firm size categories are based on the number of employees. The data for Mexico are for the year 1998, and the data for the United States are for the year 1997. The source of the Mexican data is the 1998 Mexican census of firms from INEGI. The source of the U.S. data is the 1997 U.S.

Economic Census from the U.S. Department of Commerce. Both panels report data for all firms and for manufacturing firms only.

Panel A: Share in total number of establishments, by size category

\begin{tabular}{lrrrr}
\hline & \multicolumn{2}{c}{ All firms } & \multicolumn{2}{c}{ Manufacturing firms } \\
Size category & Mexico & US & \multicolumn{1}{c}{ Mexico } & \multicolumn{1}{c}{ US } \\
\hline 0 to 9 employees & $96.09 \%$ & $78.49 \%$ & $90.29 \%$ & $56.91 \%$ \\
10 to 19 employees & $2.03 \%$ & $10.77 \%$ & $3.79 \%$ & $15.71 \%$ \\
20 to 49 employees & $1.19 \%$ & $7.79 \%$ & $2.83 \%$ & $14.38 \%$ \\
50 to 99 employees & $0.35 \%$ & $2.15 \%$ & $1.11 \%$ & $6.14 \%$ \\
100 to 499 employees & $0.30 \%$ & $1.50 \%$ & $1.58 \%$ & $5.35 \%$ \\
More than 500 employees & $0.04 \%$ & $0.30 \%$ & $0.40 \%$ & $1.52 \%$ \\
\hline Total number of establishments & $2,804,984$ & $5,295,151$ & 344,118 & 334,084 \\
\hline
\end{tabular}

Panel B: Share in total number of employees, by size category

\begin{tabular}{lrrrr}
\hline & \multicolumn{2}{c}{ All firms } & \multicolumn{2}{c}{ Manufacturing firms } \\
Size category & Mexico & US & Mexico & \multicolumn{1}{c}{ US } \\
\hline 0 to 9 employees & $38.50 \%$ & $11.35 \%$ & $18.47 \%$ & $3.53 \%$ \\
10 to 19 employees & $6.43 \%$ & $7.37 \%$ & $4.53 \%$ & $3.77 \%$ \\
20 to 49 employees & $8.91 \%$ & $10.42 \%$ & $7.40 \%$ & $7.76 \%$ \\
50 to 99 employees & $6.89 \%$ & $7.52 \%$ & $6.54 \%$ & $7.28 \%$ \\
100 to 499 employees & $18.41 \%$ & $14.86 \%$ & $28.15 \%$ & $17.32 \%$ \\
More than 500 employees & $20.87 \%$ & $48.46 \%$ & $34.90 \%$ & $60.34 \%$ \\
\hline Total number of employees & $13,827,025$ & $103,359,815$ & $4,232,322$ & $18,958,167$ \\
\hline
\end{tabular}




\section{Table 2. Legal Form of Organization Distribution in Mexico and the United States}

This table presents the percent distribution of firms by legal form of organization for Mexico and the United States. The first two columns present the share in total number of firms by legal form category and the last two columns present the share in total number of employees by legal form category. For Mexico, partnerships are sociedad de responsabilid limitada (SRLs) and corporations are sociedad anonima (SAs). For the U.S., partnerships include mostly limited liability partnerships (LLPs), but also general partnerships and limited partnerships.

\begin{tabular}{lrrrr}
\hline & \multicolumn{2}{c}{ Share in total number of firms } & \multicolumn{2}{c}{ Share in total number of employees } \\
Legal form category & México & US & México & US \\
\hline Proprietorships & $89.0 \%$ & $72.6 \%$ & $37.9 \%$ & $5.5 \%$ \\
Partnerships & $0.2 \%$ & $5.9 \%$ & $1.9 \%$ & $3.8 \%$ \\
Corporations & $8.1 \%$ & $21.0 \%$ & $50.5 \%$ & $89.4 \%$ \\
Other & $2.7 \%$ & $0.5 \%$ & $9.7 \%$ & $1.3 \%$ \\
\hline Total & $2,804,984$ & $5,295,151$ & $13,827,025$ & $103,359,815$ \\
\hline
\end{tabular}


Table 3. Firm Size, Distribution of Employment, and Ownership by State

Average firm size and employee weighted average firm size are calculated as described in the text. Share of small firms is the share of firms with 0-10 employees in total employment. Share of foreign-owned firms is the share of total employment in firms with foreign-ownership. All figures exclude firms in the electricity, water, oil and gas extraction, coal mining, and fishing sectors. All figures, except those on the share of foreign-owned firms, exclude firms with foreign ownership.

\begin{tabular}{|c|c|c|c|c|}
\hline State & Average firm size & $\begin{array}{l}\text { Employee weighted } \\
\text { average firm size }\end{array}$ & $\begin{array}{c}\text { Share of jobs, firms } \\
<10 \text { workers }\end{array}$ & $\begin{array}{c}\text { Share of foreign- } \\
\text { owned firms }\end{array}$ \\
\hline Aguascalientes & 8.3 & 918.0 & 0.45 & 0.31 \\
\hline Baja California & 42.4 & 2473.7 & 0.37 & 0.40 \\
\hline Baja California & 6.5 & 398.9 & 0.57 & 0.23 \\
\hline Campeche & 6.4 & 299.9 & 0.62 & 0.19 \\
\hline Chiapas & 5.0 & 243.9 & 0.68 & 0.13 \\
\hline Chihuahua & 11.2 & 1465.0 & 0.43 & 0.52 \\
\hline Coahuila & 31.1 & 1755.1 & 0.42 & 0.38 \\
\hline Colima & 6.5 & 309.0 & 0.58 & 0.14 \\
\hline Distrito Federal & 20.8 & 5356.4 & 0.33 & 0.25 \\
\hline Durango & 13.0 & 942.6 & 0.44 & 0.30 \\
\hline Guanajuato & 8.3 & 1214.8 & 0.48 & 0.18 \\
\hline Guerrero & 6.9 & 439.9 & 0.67 & 0.15 \\
\hline Hidalgo & 12.3 & 697.2 & 0.54 & 0.19 \\
\hline Jalisco & 12.7 & 1732.5 & 0.44 & 0.27 \\
\hline México & 19.5 & 2066.4 & 0.43 & 0.25 \\
\hline Michoacán & 7.0 & 477.8 & 0.60 & 0.12 \\
\hline Morelos & 8.1 & 520.9 & 0.56 & 0.20 \\
\hline Nayarit & 6.9 & 373.6 & 0.59 & 0.12 \\
\hline Nuevo León & 17.5 & 2672.2 & 0.37 & 0.35 \\
\hline Oaxaca & 9.3 & 352.2 & 0.61 & 0.11 \\
\hline Puebla & 9.1 & 888.0 & 0.54 & 0.23 \\
\hline Querétaro & 17.8 & 1430.0 & 0.38 & 0.28 \\
\hline Quintana Roo & 9.4 & 616.5 & 0.51 & 0.22 \\
\hline San Luis Potosí & 17.2 & 1008.8 & 0.49 & 0.23 \\
\hline Sinaloa & 11.6 & 644.1 & 0.50 & 0.22 \\
\hline Sonora & 15.9 & 1043.5 & 0.45 & 0.36 \\
\hline Tabasco & 8.3 & 601.5 & 0.58 & 0.19 \\
\hline Tamaulipas & 9.8 & 1302.7 & 0.46 & 0.35 \\
\hline Tlaxcala & 6.6 & 474.3 & 0.61 & 0.22 \\
\hline Veracruz & 46.2 & 1204.7 & 0.57 & 0.21 \\
\hline Yucatán & 10.6 & 828.5 & 0.46 & 0.25 \\
\hline Zacatecas & 11.6 & 274.6 & 0.62 & 0.16 \\
\hline Total & 13.6 & 829.5 & 0.51 & 0.24 \\
\hline
\end{tabular}


Table 4. Judicial Efficiency, Regulation, Trust, and Financial Development by State

Judicial efficiency is based on survey data from ITAM/GMA at year-end 1998 and is measured as the average of seven individual indicators (each on a scale from 0-5): Perceived quality of judges; perceived impartiality of judges; adequacy of resources for materials; efficiency in the enforcement of resolutions; efficiency of public ministry of justice; efficiency of public registry of real estate property; and adequacy of local legislation for the enforcement of contracts. Judicial efficiency are constructed such that a higher score indicates more efficiency. The measures of regulation and general trust are taken from responses to the Survey of Governance and Development of Enterprises in Mexico conducted by ITESM in 2001. Regulation is the reported percentage of sales expended on regulatory costs, averaged at the state level (expressed as a \% of sales). Generalized trust is a response on a scale of 1 (disagree) to 7 (agree) to the statement: "Most people can be trusted." Financial development is private credit to GDP in 2000 at the state-level. The data are from INEGI.

\begin{tabular}{|c|c|c|c|c|}
\hline State & Judicial efficiency & Cost of regulation & Generalized trust & $\begin{array}{c}\text { Financial } \\
\text { development }\end{array}$ \\
\hline Aguascalientes & 4.59 & 2.82 & 4.1 & 0.13 \\
\hline Baja California & 3.14 & 4.71 & 3.5 & 0.10 \\
\hline Baja California Sur & 2.53 & 3.33 & 3.9 & 0.05 \\
\hline Campeche & 3.21 & 3.73 & 3.6 & 0.03 \\
\hline Chiapas & 2.97 & 4.70 & 2.7 & 0.06 \\
\hline Chihuahua & 2.71 & 4.41 & 3.9 & 0.08 \\
\hline Coahuila & 3.40 & 2.16 & 3.8 & 0.09 \\
\hline Colima & 3.14 & 3.97 & 3.8 & 0.07 \\
\hline Distrito Federal & 2.53 & 4.38 & 3.7 & 0.67 \\
\hline Durango & 3.34 & 2.44 & 4.0 & 0.06 \\
\hline Guanajuato & 3.03 & 1.88 & 3.8 & 0.10 \\
\hline Guerrero & 1.69 & 5.57 & 3.1 & 0.03 \\
\hline Hidalgo & 2.11 & 3.55 & 3.5 & 0.03 \\
\hline Jalisco & 2.39 & 2.66 & 3.9 & 0.15 \\
\hline México & 3.20 & 4.79 & 3.5 & 0.07 \\
\hline Michoacán & 1.94 & 3.48 & 3.7 & 0.07 \\
\hline Morelos & 3.27 & 3.27 & 3.8 & 0.07 \\
\hline Nayarit & 2.49 & 2.30 & 3.7 & 0.04 \\
\hline Nuevo León & 3.00 & 3.00 & 4.1 & 0.26 \\
\hline Oaxaca & 2.64 & 4.55 & 3.5 & 0.02 \\
\hline Puebla & 2.54 & 3.49 & 3.4 & 0.10 \\
\hline Querétaro & 3.24 & 1.32 & 3.8 & 0.08 \\
\hline Quintana Roo & 2.46 & 3.88 & 4.1 & 0.10 \\
\hline San Luis Potosí & 2.84 & 2.95 & 4.1 & 0.08 \\
\hline Sinaloa & 2.67 & 2.21 & 4.0 & 0.19 \\
\hline Sonora & 3.06 & 2.61 & 4.1 & 0.18 \\
\hline Tabasco & 3.11 & 4.43 & 3.7 & 0.09 \\
\hline Tamaulipas & 3.01 & 4.51 & 3.7 & 0.06 \\
\hline Tlaxcala & 2.19 & 3.75 & 3.8 & 0.04 \\
\hline Veracruz & 2.20 & 4.42 & 3.8 & 0.06 \\
\hline Yucatán & 2.03 & 3.03 & 4.2 & 0.12 \\
\hline Zacatecas & 2.26 & 2.32 & 4.1 & 0.04 \\
\hline Total & 2.78 & 3.45 & 3.77 & 0.10 \\
\hline
\end{tabular}




\section{Table 5. Legal Forms of Organization by Sector in Mexico and the United States}

This table shows the importance of legal persons with limited liability versus physical persons with unlimited liability by industrial sector for both Mexico and the United States. Incorporation intensity is the share of legal persons with limited liability in the total number of firms. The category of legal persons with limited liability includes corporations and partnerships in the United States, and sociedades anonimas (SAs) and sociedades de responsabilidad limitada (SRLs) in Mexico. The total number of firms includes individual proprietorships. We exclude other type of legal forms from these total figures. For Mexico, we also report the share of legal persons with limited liability in the total number of employees.

\begin{tabular}{lcccc}
\hline & \multicolumn{4}{c}{ Incorporation intensity } \\
\hline Sector & Sector code & $\begin{array}{c}\text { Mexico } \\
\text { (number of firms) }\end{array}$ & $\begin{array}{c}\text { United States } \\
\text { (number of firms) }\end{array}$ & $\begin{array}{c}\text { Mexico } \\
\text { (employees) }\end{array}$ \\
\hline Mining of metals & 23 & 0.60 & 0.47 & 0.84 \\
Mining of non-metals & 29 & 0.19 & 0.61 & 0.40 \\
Food, beverages, and tobacco & 31 & 0.04 & 0.60 & 0.21 \\
Textiles and leather & 32 & 0.11 & 0.41 & 0.42 \\
Lumber products & 33 & 0.05 & 0.29 & 0.23 \\
Paper products and printing & 34 & 0.20 & 0.50 & 0.44 \\
Chemicals, pharmaceuticals, and plastics & 35 & 0.49 & 0.94 & 0.68 \\
Ceramics, glass, and clay & 36 & 0.04 & 0.41 & 0.23 \\
Basic metals & 37 & 0.78 & 0.70 & 0.89 \\
Metal products and equipment & 38 & 0.13 & 0.62 & 0.45 \\
Other manufacturing & 39 & 0.08 & 0.43 & 0.37 \\
Construction & 50 & 0.76 & 0.26 & 0.91 \\
Wholesale & 61 & 0.27 & 0.55 & 0.44 \\
Retail & 62 & 0.03 & 0.30 & 0.08 \\
Transport & 71 & 0.12 & 0.22 & 0.35 \\
Communications & 72 & 0.19 & 0.37 & 0.52 \\
Real estate & 82 & 0.29 & 0.58 & 0.42 \\
Leasing & 83 & 0.09 & 0.18 & 0.21 \\
Education and medical services & 92 & 0.03 & 0.22 & 0.08 \\
Restaurants and hotels & 93 & 0.04 & 0.48 & 0.16 \\
Recreation & 94 & 0.08 & 0.20 & 0.21 \\
Professional services & 95 & 0.09 & 0.16 & 0.36 \\
Repair and maintenance & 96 & 0.03 & 0.26 & 0.09 \\
Other services & 97 & 0.40 & 0.13 & 0.55 \\
\hline Total & & 0.20 & 0.57 & 0.38 \\
\hline
\end{tabular}




\section{Table 6. Correlation of Size and Constraint Variables}

Size is measured as the weighted average of average firm size in each of the bins, as described in the text, and also as the percentage of employment in firms with fewer than 10 workers. We also examine the percentage of employment in tradable goods sectors. On the constraints side, judicial efficiency is based on survey data from ITAM/GMA at year-end 1998 and is measured as the average of seven individual indicators (each on a scale from 0-5): Perceived quality of judges; perceived impartiality of judges; adequacy of resources for materials; efficiency in the enforcement of resolutions; efficiency of public ministry of justice; efficiency of public registry of real estate property; and adequacy of local legislation for the enforcement of contracts. Judicial efficiency is constructed such that a higher score indicates more efficiency. The measures of regulation and general trust are taken from responses to the Survey of Governance and Development of Enterprises in Mexico conducted by ITESM in 2001. Regulation is the reported percentage of sales expended on regulatory costs, averaged at the state level. generalized trust is a response on a scale of 1 (disagree) to 7 (agree) to the statement: "Most people can be trusted." Financial development is the ratio of private sector to GDP in 2000 from Mexican Statistical Institute (INEGI). Foreign ownership is the share of firms with foreign ownership. Log population are from the Mexican population census of 2000 and $\log$ GDP per capita is from the Mexican Statistical Institute (INEGI), also for 2000. Schooling is represented by the percentage of adult population in the state with at least lower secondary ( 9 years) education, measured by the 1990 census. * denotes significance at 10 percent; ** denotes significance at 5 percent; and $* * *$ denotes significance at 1 percent.

\begin{tabular}{|c|c|c|c|c|c|c|c|c|c|}
\hline & $\begin{array}{l}\text { Weighted } \\
\text { average firm } \\
\text { size }\end{array}$ & $\begin{array}{l}\% \text { of jobs in } \\
\text { firms }<10 \\
\text { workers }\end{array}$ & $\begin{array}{l}\text { Measure of } \\
\text { judicial } \\
\text { effectiveness }\end{array}$ & $\begin{array}{l}\text { Cost of } \\
\text { regulation }\end{array}$ & $\begin{array}{c}\text { Generalized } \\
\text { trust } \\
\text { measure }\end{array}$ & $\begin{array}{c}\text { Financial } \\
\text { development }\end{array}$ & $\begin{array}{l}\text { Foreign } \\
\text { ownership }\end{array}$ & $\begin{array}{c}\text { Log } \\
\text { population }\end{array}$ & $\begin{array}{l}\text { Log GDP } \\
\text { per capita }\end{array}$ \\
\hline$\%$ of jobs in firms & & & & & & & & & \\
\hline $\begin{array}{l}<10 \text { workers } \\
\text { Measure of judicial } \\
\text { effectiveness }\end{array}$ & $* * *-0.821$ & $* *-0.438$ & & & & & & & \\
\hline Cost of regulation & -0.050 & 0.262 & -0.236 & & & & & & \\
\hline $\begin{array}{l}\text { Generalized trust } \\
\text { measure }\end{array}$ & 0.235 & $* *_{-} 0.415$ & 0.150 & $* * *_{-} 0.582$ & & & & & \\
\hline $\begin{array}{l}\text { Financial } \\
\text { development } \\
\text { Foreign ownership }\end{array}$ & $* * * 0.628$ & $* * *-0.491$ & 0.031 & -0.010 & 0.170 & & & & \\
\hline & $* * * 0.683$ & $* * *-0.703$ & $* * 0.373$ & -0.073 & $* 0.342$ & 0.212 & & & \\
\hline Log population & $* * * 0.575$ & -0.073 & -0.183 & 0.272 & $*_{-}-0.314$ & $* * 0.372$ & 0.118 & & \\
\hline $\begin{array}{l}\text { Log GDP per } \\
\text { capita } \\
\text { Schooling }\end{array}$ & $* * * 0.592$ & $* * *-0.806$ & $* * 0.380$ & -0.085 & $* * 0.391$ & $* * 0.566$ & $* * * 0.641$ & -0.121 & \\
\hline & $* * * 0.653$ & $* * *-0.702$ & 0.228 & -0.026 & $* 0.327$ & $* * 0.636$ & $* * * 0.553$ & 0.034 & $* * * 0.805$ \\
\hline
\end{tabular}




\section{Table 7. Cross-State Determinants of Firm Size Distribution}

The dependent variable in panels A and B is the logarithm of the weighted average firm size calculated as described in the text, and the dependent variable in panels $\mathrm{C}$ and $\mathrm{D}$ is the share of firms with less than 10 employees in total employment of firms with less than 250 employees as described in the text. Panels A and $\mathrm{C}$ report regressions at the state/industry level with random state effects, while Panels $\mathrm{B}$ and $\mathrm{D}$ report IV regressions at the state/industry level. All regressions exclude the electricity, water, oil and gas extraction, coal mining, and fishing industries. Industry fixed effects are included, but not reported. All regressions include a measure of the size of the market, measured as the logarithm of total employment in that two-digit industry in a state. Per capita income is the log of per capita income for each state. Human capital is measures as the share of population in each state aged 15 years and over with at least 9 years of schooling education in 1990. Judicial efficiency is based on survey data from ITAM/GMA at year-end 1998 and is measured as the average of seven individual indicators (each on a scale from 0-5): Perceived quality of judges; perceived impartiality of judges; adequacy of resources for materials; efficiency in the enforcement of resolutions; efficiency of public ministry of justice; efficiency of public registry of real estate property; and adequacy of local legislation for the enforcement of contracts. Judicial efficiency is constructed such that a higher score indicates more efficiency. The measures of regulation and general trust are taken from responses to the Survey of Governance and Development of Enterprises in Mexico conducted by ITESM in 2001. Regulation is the reported percentage of sales expended on regulatory costs, averaged at the state level. generalized trust is a response on a scale of 1 (disagree) to 7 (agree) to the statement: "Most people can be trusted." Financial development is the residual of a state-level regression with the ratio of private credit to GDP as dependent variable and the measure of judicial efficiency as independent variable. The data on state-level private credit and GDP are from INEGI and for the year 2000. The regressions that control for financial development exclude the state of the Federal District. Foreign firms is the share of firms with foreign ownership in the total number of firms at the state level. Large firms is the share in employment of firms with 250 employees or more at the state/sector level. The instruments for judicial efficiency, cost of regulation, generalized trust, and access to finance are drug trafficking and the logarithm on the indigenous population in 1900, and the instrument for the size of the market is the log of state population. Heteroskedasticity-robust standard errors are reported in parentheses. Standard errors in the IV regressions correct for potential dependence of observations within states (clusters). ${ }^{*}$ denotes significance at 10 percent; $* *$ denotes significance at 5 percent; and $* * *$ denotes significance at 1 percent.

Panel A: Random effects, weighted average firm size

\begin{tabular}{lllllll}
\hline & $(1)$ & $(2)$ & $(3)$ & $(4)$ & $(5)$ & $(6)$ \\
\hline Market size & $0.617^{* * *}$ & $0.635^{* * *}$ & $0.635^{* * *}$ & $0.639^{* * *}$ & $0.615^{* * *}$ & $0.621^{* * *}$ \\
& $(0.031)$ & $(0.033)$ & $(0.034)$ & $(0.033)$ & $(0.033)$ & $(0.031)$ \\
Per capita income & 0.240 & $0.315^{*}$ & $0.369^{* *}$ & $0.277^{*}$ & 0.215 & 0.153 \\
& $(0.149)$ & $(0.164)$ & $(0.166)$ & $(0.156)$ & $(0.162)$ & $(0.148)$ \\
Schooling & 0.368 & -0.011 & 0.117 & 0.631 & 0.347 & 0.315 \\
& $(0.650)$ & $(0.735)$ & $(0.757)$ & $(0.689)$ & $(0.662)$ & $(0.629)$ \\
Judicial efficiency & $0.229^{* * *}$ & & & $0.180^{* *}$ & $0.222^{* * *}$ & $0.234^{* * *}$ \\
& $(0.074)$ & & & $(0.081)$ & $(0.078)$ & $(0.074)$ \\
General trust & & $0.343^{* *}$ & & & & $0.357^{* *}$ \\
& & $(0.151)$ & & & & $(0.161)$ \\
Cost of regulation & & & $-0.076^{*}$ & & & 0.012 \\
& & & $(0.044)$ & & & \\
Financial development & & & & 0.102 & & \\
& & & & & & $0.099)$ \\
Foreign firms & & & & & $(0.579)$ & \\
& & & & & & \\
R-squared & 0.68 & 0.68 & 0.68 & 0.68 & 0.68 & 0.69 \\
States & 32 & 32 & 32 & 31 & 32 & 32 \\
Observations & 738 & 738 & 738 & 715 & 738 & 738 \\
\hline
\end{tabular}


Panel B: Instrumental variables, weighted average firm size

\begin{tabular}{|c|c|c|c|c|c|}
\hline & (1) & $(2)$ & (3) & $(4)$ & $(5)$ \\
\hline Market size & $0.465 * * *$ & $0.541 * * *$ & $0.504 * * *$ & $0.491 * * *$ & $0.398 * * *$ \\
\hline (IV) & $(0.041)$ & $(0.076)$ & $(0.062)$ & $(0.046)$ & $(0.091)$ \\
\hline Per capita income & $\begin{array}{l}0.215 \\
(0.141)\end{array}$ & $\begin{array}{l}0.162 \\
(0.175)\end{array}$ & $\begin{array}{l}0.295^{* *} \\
(0.113)\end{array}$ & $\begin{array}{l}0.320^{* *} \\
(0.127)\end{array}$ & $\begin{array}{l}0.038 \\
(0.474)\end{array}$ \\
\hline Schooling & $\begin{array}{l}1.009 \\
(0.760)\end{array}$ & $\begin{array}{l}0.377 \\
(1.068)\end{array}$ & $\begin{array}{l}0.825 \\
(0.827)\end{array}$ & $\begin{array}{l}1.271^{*} \\
(0.707)\end{array}$ & $\begin{array}{l}0.845 \\
(0.862)\end{array}$ \\
\hline $\begin{array}{c}\text { Judicial efficiency } \\
\text { (IV) }\end{array}$ & $\begin{array}{l}0.208 * * \\
(0.091)\end{array}$ & & & & \\
\hline $\begin{array}{l}\text { General trust } \\
\text { (IV) }\end{array}$ & & $\begin{array}{l}0.854 \\
(0.596)\end{array}$ & & & \\
\hline $\begin{array}{c}\text { Cost of regulation } \\
\text { (IV) }\end{array}$ & & & $\begin{array}{l}-0.168 * \\
(0.107)\end{array}$ & & \\
\hline $\begin{array}{l}\text { Financial development } \\
\text { (IV) }\end{array}$ & & & & $\begin{array}{l}0.301 \\
(0.241)\end{array}$ & \\
\hline $\begin{array}{l}\text { Foreign firms } \\
\text { (IV) }\end{array}$ & & & & & $\begin{array}{l}2.593 \\
(3.327)\end{array}$ \\
\hline R-squared & 0.63 & 0.62 & 0.63 & 0.63 & 0.62 \\
\hline States & 32 & 32 & 32 & 31 & 32 \\
\hline Observations & 738 & 738 & 738 & 715 & 738 \\
\hline
\end{tabular}

Panel C: Random effects, share of small firms in employment

\begin{tabular}{lllllll}
\hline & $(1)$ & $(2)$ & $(3)$ & $(4)$ & $(5)$ & $(6)$ \\
\hline Market size & $-0.058^{* * *}$ & $-0.056^{* * *}$ & $-0.058^{* * *}$ & $-0.062^{* * *}$ & $-0.057^{* * *}$ & $-0.060^{* * *}$ \\
Per capita income & $(0.006)$ & $(0.006)$ & $(0.006)$ & $(0.007)$ & $(0.006)$ & $(0.005)$ \\
& $-0.080^{* * *}$ & $-0.095^{* * *}$ & $-0.087^{* * *}$ & $-0.090^{* * *}$ & $-0.076^{* *}$ & $-0.066^{* *}$ \\
Schooling & $(0.028)$ & $(0.025)$ & $(0.027)$ & $(0.030)$ & $(0.031)$ & $(0.027)$ \\
& -0.024 & -0.013 & 0.027 & -0.057 & -0.021 & -0.034 \\
Judicial efficiency & $(0.123)$ & $(0.116)$ & $(0.120)$ & $(0.133)$ & $(0.126)$ & $(0.114)$ \\
& $-0.037^{* * *}$ & & & $-0.030^{*}$ & $-0.036^{* *}$ & $-0.033^{* *}$ \\
Cost of regulation & $(0.044)$ & & & $(0.016)$ & $(0.015)$ & $(0.014)$ \\
& & $0.023^{* * *}$ & & & & 0.011 \\
General trust & & $(0.007)$ & & & & $(0.009)$ \\
& & & $-0.071^{* * *}$ & & & -0.048 \\
Financial development & & & $(0.025)$ & & & \\
& & & & 0.000 & & \\
Foreign firms & & & & & -0.042 & \\
& & & & & $(0.109)$ & \\
Large firms & -0.044 & -0.052 & -0.048 & -0.042 & -0.043 & \\
& $(0.045)$ & $(0.045)$ & $(0.046)$ & $(0.047)$ & $(0.045)$ & \\
R-squared & & & & & \\
States & 0.68 & 0.68 & 0.68 & 0.68 & 0.68 & 0.68 \\
Observations & 32 & 32 & 32 & 31 & 32 & 32 \\
\hline
\end{tabular}


Panel D: Instrumental variables, share of small firms in employment

\begin{tabular}{rlll}
\hline & $(1)$ & $(2)$ & $(3)$ \\
\hline Market size & $-0.031^{* * *}$ & $-0.041^{* * *}$ & $-0.036^{* * *}$ \\
(IV) & $(0.007)$ & $(0.009)$ & $(0.008)$ \\
Per capita income & $-0.078^{* *}$ & $-0.071^{* *}$ & $-0.089^{* * *}$ \\
Schooling & $(0.038)$ & $(0.027)$ & $(0.026)$ \\
Judicial efficiency & -0.147 & -0.057 & -0.121 \\
(IV) & $(0.140)$ & $(0.149)$ & $(0.120)$ \\
General trust & $-0.030^{*}$ & & \\
(IV) & $(0.017)$ & & \\
Cost of regulation & & -0.121 & \\
(IV) & & $(0.089)$ & 0.024 \\
R-squared & & & $(0.014)$ \\
States & & & \\
Observations & 0.67 & 0.67 & 0.67 \\
\hline
\end{tabular}




\section{Table 8. Firm Size Distribution and Legal Form}

The dependent variable is the weighted average firm size calculated as described in the text. All regressions include a measure of the size of the market, measured as the logarithm of total employment in that twodigit industry in a state. Per capita income is the log of per capita income for each state. Human capital is measures as the share of population in each state aged 15 years and over with at least 9 years of schooling education in 1990. Judicial efficiency is based on survey data from ITAM/GMA at year-end 1998 and is measured as the average of seven individual indicators (each on a scale from 0-5): Perceived quality of judges; perceived impartiality of judges; adequacy of resources for materials; efficiency in the enforcement of resolutions; efficiency of public ministry of justice; efficiency of public registry of real estate property; and adequacy of local legislation for the enforcement of contracts. Judicial efficiency is constructed such that a higher score indicates more efficiency. The incorporation intensity variable used in panel A is based on data from the 1998 Mexican Economic census, while for panel B this variable is based on data from the 1997 U.S. Economic Census. Column (1) in Panels A and B reports OLS estimates with industry fixed effects and state fixed effects (not reported) and heteroskedasticity-robust standard errors. Column (2) in Panels A and B is estimated using random state effects with industry fixed effects (not reported). Column (3) in Panels A and B is estimated using IV and do not include state fixed effects, but do include industry fixed effects (not reported). The instruments for judicial efficiency and generalized trust are drug trafficking and the logarithm on the indigenous population in 1900, and the instrument for the size of the market is the log of state population. Standard errors in the IV regressions correct for potential dependence of observations within states (clusters). All regressions exclude the electricity, water, oil and gas extraction, coal mining, and fishing industries. The regressions in panel B also exclude the construction industry. * denotes significance at 10 percent; ** denotes significance at 5 percent; and *** denotes significance at 1 percent.

Panel A: Mexican data for incorporation intensity

\begin{tabular}{llll}
\hline & $\begin{array}{l}\text { Fixed effects } \\
(1)\end{array}$ & $\begin{array}{l}\text { Random effects } \\
(2)\end{array}$ & $\begin{array}{l}\text { Instrumental variables } \\
(3)\end{array}$ \\
\hline Market size & $0.744^{* * *}$ & $0.624^{* * *}$ & $0.469^{* * *}$ \\
& $(0.053)$ & $(0.032)$ & $(0.043)$ \\
Per capita income & & 0.239 & 0.218 \\
& & $(0.152)$ & $(0.146)$ \\
Schooling & & 0.367 & 1.034 \\
& & $(0.661)$ & $(0.780)$ \\
Judicial efficiency & & $0.379^{* * *}$ & $0.478^{* * *}$ \\
& & $(0.093)$ & $(0.149)$ \\
General trust & & & \\
Judicial efficiency $*$ & $-0.857^{* * *}$ & $-0.797 * * *$ & $-1.479^{* *}$ \\
Incorporation intensity & $(0.283)$ & $(0.285)$ & $(0.707)$ \\
& & & \\
R-squared & 0.71 & 0.68 & 0.67 \\
States & 32 & 32 & 32 \\
Observations & 738 & 738 & 738 \\
\hline
\end{tabular}


Panel B: U.S. data for incorporation intensity

\begin{tabular}{llll}
\hline & $\begin{array}{l}\text { Fixed effects } \\
(1)\end{array}$ & $\begin{array}{l}\text { Random effects } \\
(2)\end{array}$ & $\begin{array}{l}\text { Instrumental variables } \\
(3)\end{array}$ \\
\hline Market size & $0.739^{* * *}$ & $0.625^{* * *}$ & $0.476^{* * *}$ \\
& $(0.054)$ & $(0.032)$ & $(0.038)$ \\
Per capita income & & $0.271^{*}$ & 0.233 \\
& & $(0.154)$ & $(0.152)$ \\
Schooling & & 0.229 & 0.891 \\
& & $(0.671)$ & $(0.781)$ \\
Judicial efficiency & & $0.492^{* * *}$ & $0.609^{* * *}$ \\
& $-0.641^{* *}$ & $(0.143)$ & $(0.209)$ \\
Judicial efficiency $*$ & $(0.268)$ & $\left(0.578^{* *}\right.$ & $-0.872^{*}$ \\
Incorporation intensity U.S. & & & $(0.484)$ \\
& 0.69 & 0.66 & \\
R-squared & 32 & 32 & 0.65 \\
States & 706 & 706 & 32 \\
Observations & & & 706 \\
\hline
\end{tabular}




\section{Appendix Table 1. Components of Judicial Effectiveness Variables}

Judicial efficiency is based on survey data from ITAM/GMA at year-end 1998 and is measured as the average of seven individual indicators (each on a scale from 0-5): Perceived quality of judges; perceived impartiality of judges; adequacy of resources for materials; efficiency in the enforcement of resolutions; efficiency of public ministry of justice; efficiency of public registry of real estate property; and adequacy of local legislation for the enforcement of contracts. Judicial efficiency are constructed such that a higher score indicates more efficiency. Additional measures are the percentage of the state's budget dedicated to the judiciary branch, the salary of judges relative to workers with university education in the private sector, and the average number of months needed to prosecute a case involving collection of bank debt. All measures of judicial efficiency except duration of cases are constructed such that a higher score indicates more efficiency. $*$ denotes significance at 10 percent; $* *$ denotes significance at 5 percent; and ${ }^{* * *}$ denotes significance at 1 percent.

\begin{tabular}{|c|c|c|c|c|c|c|c|c|c|c|}
\hline & $\begin{array}{l}\text { Quality of } \\
\text { judges }\end{array}$ & $\begin{array}{l}\text { Impartiality } \\
\text { of judges }\end{array}$ & $\begin{array}{l}\text { Adequacy of } \\
\text { resources }\end{array}$ & $\begin{array}{l}\text { Efficiency of } \\
\text { enforcement }\end{array}$ & $\begin{array}{l}\text { Efficiency of } \\
\text { ministry of } \\
\text { justice }\end{array}$ & $\begin{array}{l}\text { Efficiency of } \\
\text { public } \\
\text { registry } \\
\end{array}$ & $\begin{array}{l}\text { Adequacy of } \\
\text { local laws }\end{array}$ & $\begin{array}{c}\text { Judicial } \\
\text { budget }\end{array}$ & $\begin{array}{l}\text { Salary of } \\
\text { judges }\end{array}$ & $\begin{array}{c}\text { Duration of } \\
\text { cases }\end{array}$ \\
\hline \multicolumn{11}{|l|}{$\begin{array}{l}\text { Impartiality } \\
\text { of judges }\end{array}$} \\
\hline \multicolumn{11}{|l|}{$\begin{array}{l}\text { Adequacy of } \\
\text { resources }\end{array}$} \\
\hline & 0.293 & $* * * 0.648$ & & & & & & & & \\
\hline \multicolumn{11}{|l|}{$\begin{array}{l}\text { Efficiency of } \\
\text { enforcement }\end{array}$} \\
\hline & -0.040 & 0.231 & $* * * 0.468$ & & & & & & & \\
\hline $\begin{array}{l}\text { Efficiency of } \\
\text { ministry of } \\
\text { justice }\end{array}$ & -0.076 & 0.222 & $* * 0.427$ & $* * * 0.994$ & & & & & & \\
\hline $\begin{array}{l}\text { Efficiency of } \\
\text { public }\end{array}$ & & & & & & & & & & \\
\hline $\begin{array}{l}\text { registry } \\
\text { Adequacy of }\end{array}$ & $* 0.388$ & $* 0.307$ & $* 0.307$ & 0.068 & 0.021 & & & & & \\
\hline & -0.126 & -0.171 & 0.048 & $* 0.343$ & $* 0.328$ & -0.152 & & & & \\
\hline \multicolumn{11}{|l|}{$\begin{array}{l}\text { Judicial } \\
\text { budget }\end{array}$} \\
\hline & 0.029 & $* * * 0.559$ & 0.255 & 0.143 & 0.135 & -0.012 & -0.150 & & & \\
\hline \multicolumn{11}{|l|}{$\begin{array}{l}\text { Salary of } \\
\text { judges }\end{array}$} \\
\hline & 0.025 & -0.239 & 0.232 & 0.270 & 0.231 & -0.194 & $* * 0.356$ & -0.083 & & \\
\hline \multicolumn{11}{|l|}{$\begin{array}{l}\text { Duration of } \\
\text { cases }\end{array}$} \\
\hline & $* *-0.352$ & -0.222 & -0.258 & -0.004 & 0.050 & -0.107 & 0.121 & -0.022 & -0.239 & \\
\hline $\begin{array}{l}\text { Overall } \\
\text { measure of } \\
\text { judicial } \\
\text { effectiveness }\end{array}$ & $* 0.333$ & $* * * 0.606$ & $* * * 0.799$ & $* * * 0.776$ & $* * * 0.743$ & $* 0.334$ & $* * 0.334$ & 0.253 & 0.204 & -0.174 \\
\hline
\end{tabular}

